\title{
REVIEW
}

\section{The effect of adipocyte-macrophage crosstalk in obesity-related breast cancer}

\author{
Ayse Basak Engin', Atilla Engin² and Ipek Isik Gonul³ \\ 1Department of Toxicology, Faculty of Pharmacy, Gazi University, Ankara, Turkey \\ 2Department of General Surgery, Faculty of Medicine, Gazi University, Ankara, Turkey \\ 3Department of Pathology, Faculty of Medicine, Gazi University, Ankara, Turkey
}

Correspondence should be addressed to A B Engin: abengin@gmail.com

\begin{abstract}
Adipose tissue is the primary source of many pro-inflammatory cytokines in obesity. Macrophage numbers and pro-inflammatory gene expression are positively associated with adipocyte size. Free fatty acid and tumor necrosis factor- $\alpha$ involve in a vicious cycle between adipocytes and macrophages aggravating inflammatory changes. Thereby, M1 macrophages form a characteristic 'crown-like structure (CLS)' around necrotic adipocytes in obese adipose tissue. In obese women, CLSs of breast adipose tissue are responsible for both increase in local aromatase activity and aggressive behavior of breast cancer cells. Interlinked molecular mechanisms between adipocyte-macrophage-breast cancer cells in obesity involve seven consecutive processes: Excessive release of adipocyte- and macrophage-derived inflammatory cytokines, TSC1-TSC2 complex-mTOR crosstalk, insulin resistance, endoplasmic reticulum (ER) stress and excessive oxidative stress generation, uncoupled respiration and hypoxia, SIRT1 controversy, the increased levels of aromatase activity and estrogen production. Considering elevated risks of estrogen receptor (E2R)-positive postmenopausal breast cancer growth in obesity, adipocytemacrophage crosstalk is important in the aforementioned issues. Increased mTORC1 signaling in obesity ensures the strong activation of oncogenic signaling in E2R $\alpha$-positive breast cancer cells. Since insulin and insulin-like growth factors have been identified as tumor promoters, hyperinsulinemia is an independent risk factor for poor prognosis in breast cancer despite peripheral insulin resistance. The unpredictable effects of adipocyte-derived leptin-estrogen-macrophage axis, and sirtuin 1 (SIRT1)-adiposeresident macrophage axis in obese postmenopausal patients with breast cancer are unresolved mechanistic gaps in the molecular links between the tumor growth and adipocytokines.
\end{abstract}

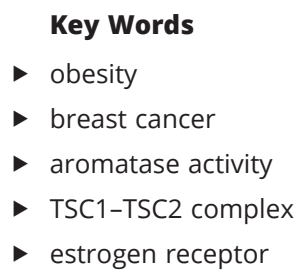

Journal of Molecular Endocrinology (2019) 62, R201-R222

\section{Introduction}

Obesity is mainly dependent on excessive fat accumulation in the regional adipose tissues. In obese individuals, more adipocytes release more adipocytokines. Large breast volume is proportional to the fat storage in the visceral and intermuscular depots in obese premenopausal women (Janiszewski et al. 2010). Postmenopausal patients with high visceral fat area have significantly shorter distant disease-free survival than premenopausal patients in breast cancer series (Iwase et al. 2016). Furthermore, peri-tumoral fat ratio significantly correlates with the 
positive axillary lymph nodes among obese patients with breast cancer (Obeid et al. 2017). In this context, the release of excessive inflammatory cytokines from hypertrophic adipocytes, and increase in inflammatory pathway activity due to increases in number of adipose tissue macrophages (ATMs) are important contributing factors to the pathogenesis of obesity-related diseases. Eventually, these biologically active polypeptides promote the inflammatory, endocrine, paracrine and autocrine pathways during the progression of breast cancer (Li \& Han 2018). In fact, breast cancer results from interactions of various factors. Besides the genetic predisposition and obesity, aging is one of the important conditions that promotes the disease. According to the American Cancer Society, the most invasive breast cancer cases are reported among women aged 55 years or more (Minakshi et al. 2017). Therefore, the relationship between the prevalence of obesity and increased risk of invasive breast cancer should be considered, especially in postmenopausal women (Ng et al. 2014, Zhao et al. 2018). In postmenopausal women, the link between obesity and breast cancer is closely related to the hormonal imbalance and the release of growth factors and inflammatory cytokines by adipocytes (Lukanova et al. 2004). In a clinical study that involved a total of 16,608 women without hysterectomy, the patients were randomized for the estrogen-plus-progestin trial. In the estrogen-plusprogestin group, breast cancer incidence was higher, and the cases were more commonly lymph node positive (Chlebowski et al. 2010). However, obese, never users of hormone therapy have 1.7 -fold to 2.3 -fold elevated risks of ductal and E2R-positive-progesterone receptor (PR)positive breast cancer, respectively, compared to thinner women (Li et al. 2006). In a large percentage of patients with invasive breast cancers, increasing central obesity is significantly associated with continuous elevation in risk of postmenopausal breast cancer. This relationship can be explained by the excessive endogenous estrogen production of breast adipose tissue adjacent to cancer cells observed in obesity (Guo et al. 2018). Thus, obese women have 35\% higher concentrations of estrone and $130 \%$ higher concentrations of estradiol compared to normal weight women (McTiernan et al. 2003). There is abundance of data linking obesity-related breast cancer and E2R signaling. The comorbidities of obesity such as excessive local production of estrogens in adipose tissue, the influence of adipokines and inflammatory cytokines have been specified as independent risk factors for breast cancer in postmenopausal women (Boyd \& McGuire 1990, McDonnell et al. 2014). Despite systemic estradiol declines in menopause, the incidence of E2Ro-positive breast cancer dramatically increases (Pfeilschifter et al. 2002, Sasser et al. 2007). In this regard, obesity-related breast inflammation is critical for the induction of aromatase activity. Aromatase also mediates the crosstalk of obesity-associated inflammation and hormone alterations in breast cancer (Subbaramaiah et al. 2012). However, aromatase inhibitors in breast cancer therapy are less efficient at suppressing estradiol serum levels in obese when compared with nonobese women (Pfeiler et al. 2013). Eventually, interlinked molecular mechanisms between adipocyte-macrophagebreast cancer cells in obesity involve seven consecutive processes: overexpression of adipocyte- and macrophagederived inflammatory cytokines, tuberous sclerosis proteins 1 (hamartin)-2 (tuberin) (TSC1-TSC2) complexmammalian target of rapamycin (mTOR) crosstalk, insulin resistance and hyperactivation of insulin-like growth factors (IGFs)-related pathways, the increased levels of aromatase activity, ER stress and excessive oxidative stress generation, uncoupled respiration and hypoxia, Sirtuin 1 (SIRT1) controversy (Simone et al. 2016). Regarding the continuous flow and accumulation of new macrophages/ monocytes from circulation to adipose tissue in obesity, crosstalk between adipocytes and ATMs is an important process that initiates the chronic inflammation in obese adipose tissue (Bai \& Sun 2015). In this review, unlike the previous studies, the effects of above-mentioned seven consecutive processes on the biological behavior of breast cancer have been reappraised by considering the crosstalk between adipocyte-macrophage-breast cancer cells in obesity.

\section{Adipocyte-macrophage interaction}

Adipose tissue is the primary source of many proinflammatory cytokines, but ATMs, which are important cellular components of adipose tissue, have key regulatory functions in inflammation, insulin resistance and adipocyte functions (Russo \& Lumeng 2018). ATMs are responsible for almost all adipose tissue tumor necrosis factor-alpha (TNF- $\alpha$ ) expression and significant amounts of nitric oxide and interleukin-6 (IL-6) expression. Indeed, macrophage-derived cytokines lead to a chronic low-grade inflammatory state that is crucial in the pathogenesis of obesity-related pathological conditions (Weisberg et al. 2003, Lee \& Lam 2018). Furthermore, macrophage numbers and pro-inflammatory gene expression in adipose tissue are not only positively associated with adipocyte size, but also negatively associated with weight loss in 
obese individuals (Weisberg et al. 2003, Clément et al. 2004). Therefore, both body mass index (BMI) and average adipocyte size are significant predictors of macrophage accumulation in adipose tissue. In this context, the crosstalk between adipocytes and macrophages provokes the initiation of chronic inflammation in obese adipose tissue as well as exacerbating the inflammatory process (Wellen \& Hotamisligil 2003). Approximately 10\% of adipocytes are renewed annually by a continuous turnover. Low generation rates of adipocytes associate with adipose tissue hypertrophy (Spalding et al. 2008, Arner et al. 2010). Apoptotic old adipocytes are removed by macrophages (Duvall et al. 1985, Keuper et al. 2011). Necrosis of adipocytes driven by hypertrophy is a prominent phagocytic stimulus that regulates ATM infiltration which is gradually increased by obesity (Cinti et al. 2005). Apoptotic cells send an 'eat me' signal to macrophages, triggering their own engulfment (Krahling et al. 1999). Galectin-3 expression at sites of adipocyte necrosis and hypertrophic adipocyte-derived chemotactic 'monocyte chemoattractant protein-1 (MCP-1)/CC chemokine receptor 2 (CCR2)' pathway promotes macrophage accumulation into the obese adipose tissue (Cinti et al.
2005, Kanda et al. 2006). Infiltration of cytotoxic T cells into obese adipose tissue is thought to precede macrophage accumulation. T-cell-derived cytokines such as interferongamma (IFN- $\gamma$ ) promote the recruitment and activation of M1 macrophages, thereby adipose tissue inflammation is enhanced (Harford et al. 2011). While TNF- $\alpha$ induces inflammation in adipocytes as a major macrophagederived mediator, adipocyte-derived free fatty acids (FFAs) induce inflammatory cytokines and chemokines expression in macrophages. Thus, pro-inflammatory adipokines of adipose tissue, such as MCP-1 and TNF- $\alpha$, and saturated fatty acids released from adipocytes interact with toll-like receptor 4 (TLR4) complex, inducing nuclear factor kappa-light chain enhancer of activated B cells (NF$\kappa \mathrm{B})$ activation in resident macrophages. TLRs are the most well-characterized sensors that detect exogenous 'danger signals pattern-recognition receptor'. Saturated fatty acids that are released from hypertrophic adipocytes serve as a ligand for TLR4 (Fig. 1). Inflammatory process activation in obesity is initiated by 'adipocyte-macrophage-TLR4' pathway (Suganami et al. 2005, 2007, Wolowczuk et al. 2008). Thus, macrophages discriminate other molecular patterns from self-proteins through expression of pattern-

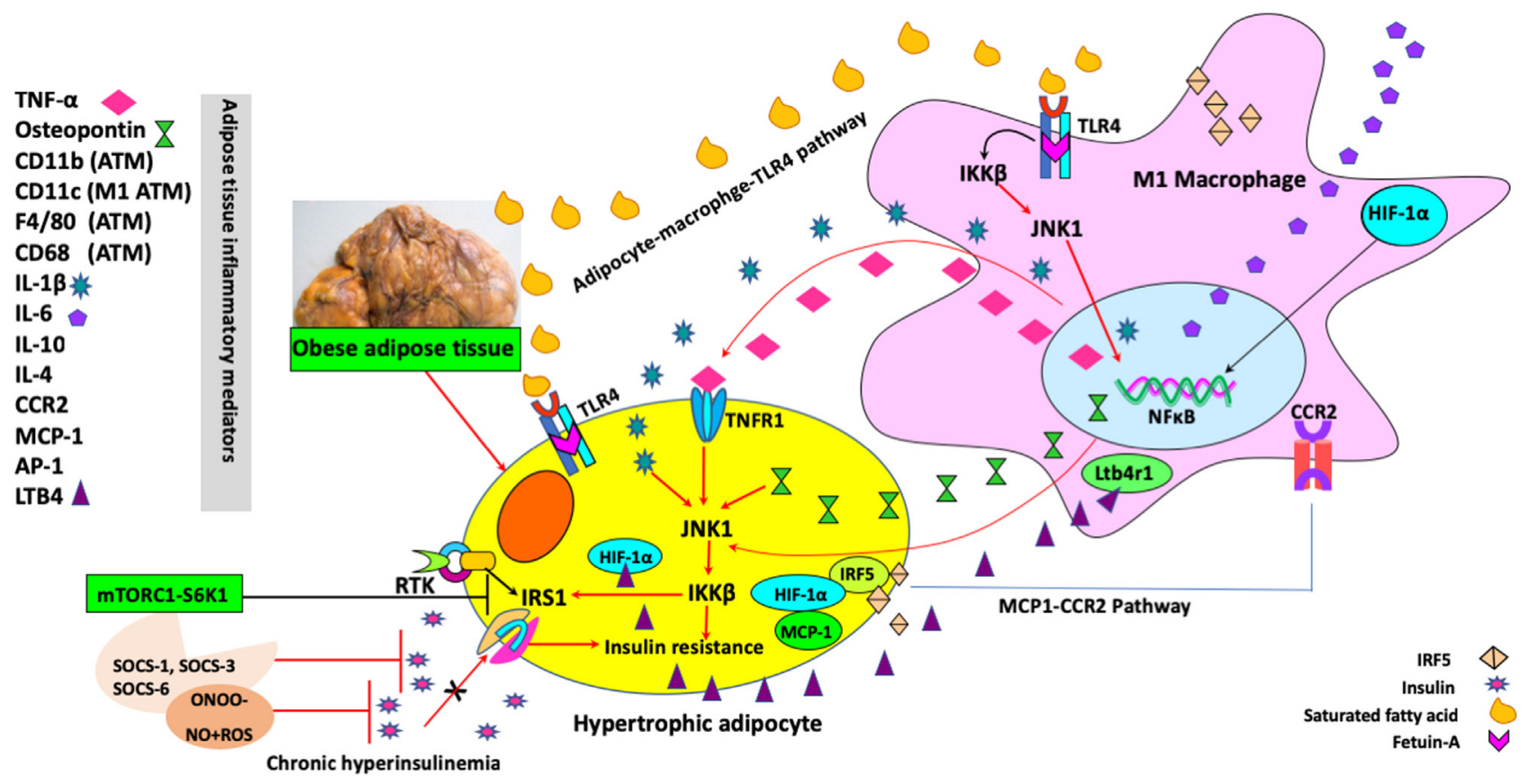

Figure 1

While TNF- $\alpha$ induces JNK1-IKK $\beta$ pathway in adipocytes as a major macrophage-derived mediator, hypertrophic adipocytes-derived saturated fatty acid serves as a ligand for TLR4 and induces inflammatory cytokines and chemokines expression in macrophages as well as adipocytes. AP-1, activating protein-1; CCL2, CCR2-chemokine (C-C motif) receptor ligand $2 ;$ HIF-1 $\alpha$, hypoxia-inducible factor- $1 \alpha$; IKK $\beta$, inhibitor kappa B kinase- $\beta$; IL-1 $\beta$, interleukin-1 $\beta$; IRF5, interferon regulatory factor-5; IRS-1, insulin receptor substrate-1; JNK, c-Jun N-terminal kinase; LTB4, leukotriene B4; Itb4r1, leukotriene B4-G protein-coupled receptor; MCP-1, monocyte chemoattractant protein-1; mTORC1, mammalian target of rapamycin complex 1; NFkB, nuclear factor-kappa B; NO, nitric oxide; ONOO-, peroxynitrite; ROS, reactive oxygen species; RTK, receptor tyrosine kinase; S6K, ribosomal protein S6 kinase-1; SOCS3, suppressor of cytokine signaling 3; TLR4, toll-like receptor 4; TNF- $\alpha$, tumor necrosis factor- $\alpha$; TNFR1, TNF receptor-1. 
recognition receptors, such as TLRs (Barton \& Kagan 2009). Obesity-induced elevation in saturated FFAs induces insulin resistance by activating the TLR4-mediated signaling in both macrophages and adipocytes (Shi et al. 2006). However, FFAs do not directly bind to TLR4, fetuin-A is required as an endogenous ligand for TLR4 (Pal et al. 2012). Furthermore, macrophages can recognize the injured or damaged cell-derived 'danger-associated molecular patterns' and release pro-inflammatory cytokines. Members of the Nod-like receptor family, including NLRP3 and the adaptor apoptosis-associated speck-like protein containing CARD (ASC) are critical components of the inflammasome that link endogenous danger signals to caspase- 1 activation leading to chronic inflammation (Franchi et al. 2009). Saturated fatty acids can trigger inflammation by activating inflammasomes (NLRP3) and induce macrophages (Wen et al. 2011). The NLRP3 senses lipotoxicity-associated danger signals that are increased in intracellular ceramide to induce caspase-1 cleavage in macrophages, and contributes to insulin resistance (Vandanmagsar et al. 2011). Macrophageinducible C-type lectin (Mincle) is induced selectively in macrophages during the interaction between adipocytes and macrophages. Saturated fatty acid released from adipocytes induces Mincle mRNA expression in macrophages through the TLR4/NF-кB pathway. Macrophage-induced adipocyte lipolysis aggravates obesity-induced adipose tissue inflammation by this way (Ichioka et al. 2011). TLR-dependent polarization mediators of M1 macrophages include different transcription factors such as NF- $\mathrm{B}$, activator protein-1 (AP-1), transcription factor PU.1 (PU.1), CCAAT/enhancer-binding protein $\alpha$ $(\mathrm{C} / \mathrm{EBP}-\alpha)$, signal transducer and activator of transcription 1 (STAT1) as well as interferon regulatory factor-5 (IRF5) (Juhas et al. 2015). High expression of IRF5 is characteristic for M1 macrophages and it is negatively associated with insulin sensitivity in visceral adipose tissue (Krausgruber et al. 2011, Dalmas et al. 2015). Differentiation of M1 macrophages are dependent on the upregulation of IRF5 levels (Juhas et al. 2015). In fact, obesity is accompanied by a transformation in the polarized states of macrophages from an anti-inflammatory 'alternatively activated' M2 form, to a more pro-inflammatory 'classically activated' M1 form (Lumeng et al. 2007a, Kosteli et al. 2010). While the microenvironment in a lean adipose tissue is composed of a 4:1, M2:M1 ratio, obesity increases the number of M1 macrophages by 65 -fold. Whereas the number of M2 macrophages per weight basis is also increased by six-fold. Thus, the ratio of M1-to-M2 macrophages is increased in obesity (Lumeng et al. 2008, Fujisaka et al. 2009).
Once infiltrated into the adipose tissue, macrophages become mature and interact with adipocytes. A paracrine loop involving FFAs and TNF- $\alpha$ between adipocytes and macrophages establishes a vicious cycle that aggravates inflammatory changes in the adipose tissue (Suganami et al. 2005). Because of this mutual relationship, macrophages form a characteristic crown-like structures (CLS) around necrotic adipocytes (Weisberg et al. 2003, Cinti et al. 2005, Murano et al. 2008, Olefsky \& Glass 2010). CLS-associated macrophages intensely produce pro-inflammatory mediators (Kern et al. 2001, Xu et al. 2003, Olefsky \& Glass 2010, Suganami \& Ogawa 2010). Exposure of adipose tissue to Th2 cytokines, such as IL-4, IL-13 and granulocyte-macrophage colony-stimulating factor (GM-CSF), stimulates ATM proliferation, whereas Th1 cytokines, such as TNF- $\alpha$, inhibit local ATM proliferation. CLSs exhibit a unique microenvironment for macrophage proliferation. Interestingly, locally proliferating macrophages are not classically activated (M1) type, but they have alternatively activated (M2) immune phenotype. IL-6 as a Th2 cytokine, stimulates M2 polarization and local ATM proliferation in obesity (Braune et al. 2017). There is a shift toward a M2 phenotype in non-CLS macrophages in adipose tissue from obese subjects compared with lean ones. Macrophages in CLS are predominantly $\mathrm{M} 1$, but most other macrophages, particularly those in fibrotic areas, are M2 (Spencer et al. 2010). CLSs in the white adipose tissue of the breast (CLSB) in obese women with breast cancer are responsible for both increase in local aromatase activity, and enhanced invasiveness and metastasis capacity of breast cancer. As a matter of fact, the main mechanism that increases the risk of breast cancer in postmenopausal women is the excessive estrogen production of obese adipose tissue due to high aromatase activity of adipocytes (Rose \& Vona-Davis 2014). Since ATMs are selectively localized to dead adipocytes, clearance of free lipid appears to be an important function of galectin-3 (MAC-2)-expressing macrophages (Cinti et al. 2005). Therefore, increased local extracellular lipid concentrations drive ATM infiltration to adipose tissue. A part of the FFAs released from necrotic adipocytes are transported to adjacent adipocytes, while the rest are taken by macrophages. Despite the presence of large quantities of lipid-filled macrophages in CLSs, increased flux of non-esterified fatty acids from apoptotic adipocytes indicate the lipid buffering capacity of ATMs is surpassed (Thompson et al. 2010, Shapiro et al. 2013, Boutens \& Stienstra 2016). CLS-B in obese women with breast cancer indicates the relationship between inflammation and aromatase activity, and at the same 
time points to the increased breast cancer risk and poor prognosis (Morris et al. 2011). Breast inflammation defined by CLS-B is paralleled by increased NF-kBbinding activity and elevated levels of aromatase mRNA and aromatase activity. Besides the aromatase activity, cyclooxygenase-2 (COX-2), prostaglandin E2 (PGE2), cyclic adenosine monophosphate (cAMP) and protein kinase A (PKA) activities more strongly correlate with the CLS-B index (severity of breast inflammation) than with BMI (Morris et al. 2011). Additional important factors increasing breast cancer risks in obesity are adipocyte-related hyperleptinemia and obesity-related hyperinsulinemia (Rose \& Vona-Davis 2014). Thus, leptin overexpression by the resident adipocytes in breast cancer tissue compared with adjacent healthy tissues is a serious factor promoting malignant growth in breast tissue (Liang et al. 2018). The crosstalk between leptin and aromatase increases estrogen levels. This effect of leptin is mediated through the mitogen-activated protein kinase (MAPK)/'extracellular signal-regulated kinase 1/2 (ERK1/2)'-STAT3 and phosphoinositide 3-kinase (PI3K) pathways (Masarwi et al. 2018). Consequently, adipocytederived leptin participates in cell growth and angiogenesis during breast cancer development by enhancing estrogen effects on malignant tissue via a paracrine pathway (Gonzalez et al. 2006, Schmidt et al. 2015). Since STAT proteins have an important role in the development of breast cancer, downregulation of STAT3 and STAT5a/b has been suggested as a mechanism for anti-proliferative effects of some anticancer agents in breast cancer cells. Methylsulfonylmethane (MSM), which is an organic sulfur-containing natural compound without any toxicity, suppresses the phosphorylation of STAT3 and STAT5b in E2R $\alpha$-positive breast cancer cells. Moreover, MSM decreases the DNA-binding activities of STAT5b and STAT3, to the target gene promoters (Lim et al. 2012). Synergy between the leptin/leptin receptor/STAT3 signaling pathway and the human epidermal growth factor receptor 2 (HER2) protects tamoxifen-treated HER2 overexpressing cells from the inhibitory effect of tamoxifen through differential regulation of apoptosis-related genes (Papanikolaou et al. 2015). Elevated serum levels of leptin maintain resistance to anti-estrogen drugs during hormonal therapy of breast cancer (Garofalo et al. 2004). On the other hand, leptin-mediated crosstalk between tumorassociated macrophages (M2 macrophages) and breast cancer cells shows that adipocytes provoke tumor growth and metastasis via stimulating IL-8 production of tumorassociated macrophages (TAMs). Eighty-three percent of breast cancer cases have leptin receptors. In accordance with this, distant metastasis is detected in $34 \%$ of all leptin receptor-positive tumors with leptin overexpression, but none of the patients with leptin receptor-negative and weak leptin expressing tumors are found to have distant metastasis (Ishikawa et al. 2004). Leptin-cytokine signaling pathways are also responsible for increasing the secretion of adipokines from both adipocytes and TAMs in obesity (Newman \& Gonzalez-Perez 2014). It can be stated that, leptin is an important biomarker that could identify relapse and prognosis in breast cancer via adipocyte-macrophage interaction (Khabaz et al. 2017). Although, leptin receptor expression in primary breast cancer is positively correlated with estrogen receptor (E2R) expression, anti-estrogen therapy increases serum leptin levels in obese postmenopausal breast cancer patients due to stimulation of the synthesis and release of leptin in the adipocytes. Therefore, anti-proliferative efficacy of antiestrogen drugs are attenuated. Thereby, obesity promotes therapeutic escape in breast cancer (Marttunen et al. 2000, Jardé et al. 2008, Bougaret et al. 2018).

\section{TSC1-TSC2 complex-mTOR crosstalk}

All these factors form an inflammatory microenvironment to regulate the biological function of transcription factors. Approximately $70-75 \%$ of breast cancers express the E2R, which indicates the estrogen dependency for tumor growth. When activated by $17 \beta$-estradiol, E2R $\alpha$ plays an important role in the stimulation of cancer cell proliferation and prevention of apoptosis (Ali \& Coombes 2000). The PI3K/protein kinase B (AKT)/mTOR pathway is a key intracellular signaling system that drives cellular growth and survival. Activation levels of this pathway determine the growth rate of E2R-positive breast cancer. Eventually, estrogen dependency of breast cancer cells also determines the prognosis of patients (Ciruelos Gil 2014). E2Ro-expressing tumors represent the largest group of breast cancer patients indicating that more women die from E2R $\alpha$-positive breast tumors than from other more malignant breast cancer subtypes (Molina et al. 2017).

In fact, mTOR is an atypical serine/threonine-protein kinase that belongs to the PI3K-related kinase family and interacts with several proteins to form two large protein complexes called mTOR complex 1 (mTORC1) and 2 (mTORC2) (Loewith et al. 2002) (Fig. 2). In adipocytes, mTOR-mediated phosphorylation at Ser501/503 changes the binding site of adaptor protein Growth factor receptor binding protein-10 (Grb10) from the insulin receptor to Raptor (Regulatory-associated protein of mTOR). The dissociation of Raptor from mTOR results in 


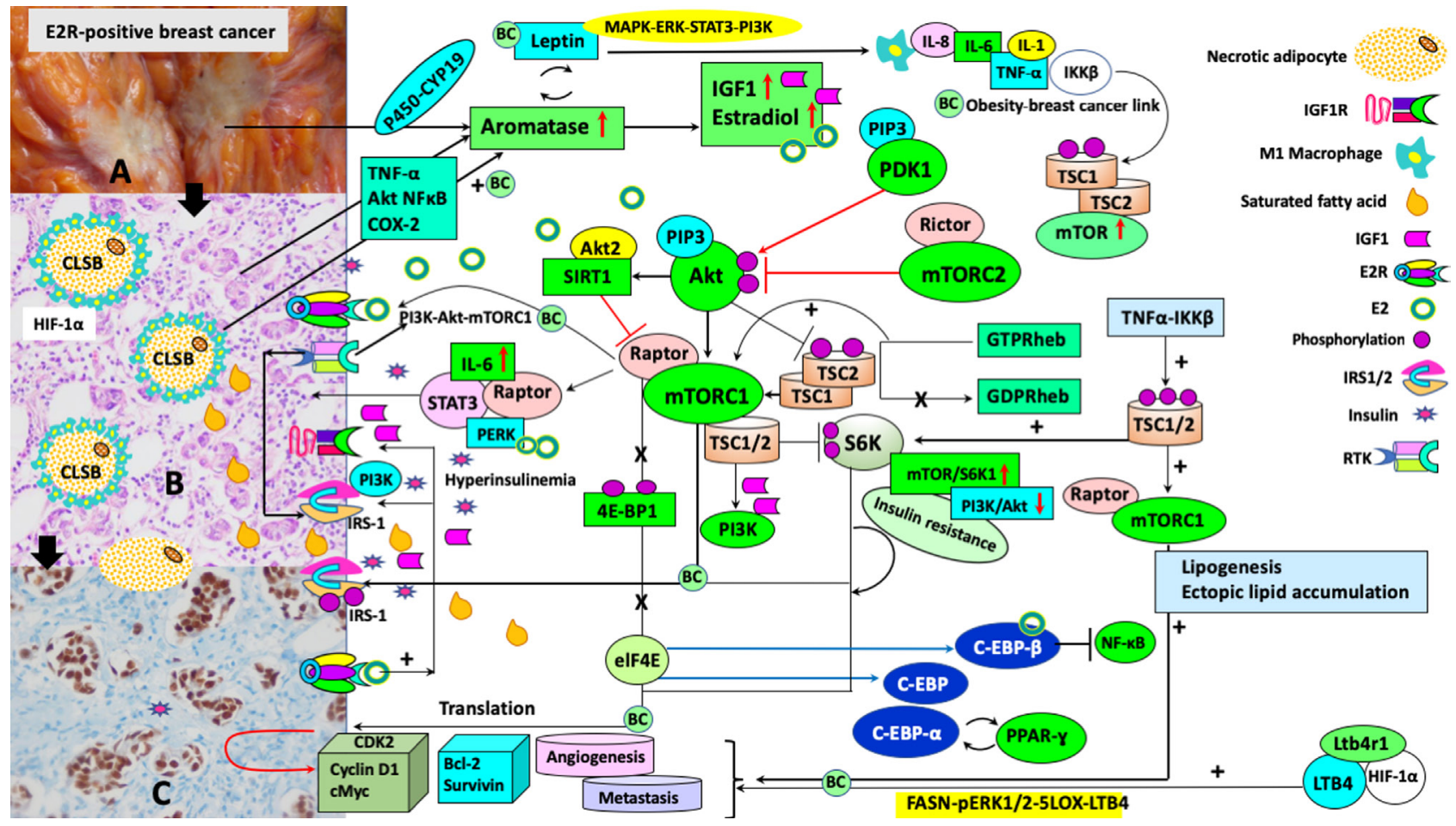

\section{Figure 2}

Connections between obesity and breast cancer. The extensive crosstalk between the E2R and PI3K/Akt/mTORC1 pathways is critical for invasiveness and metastasis capacity of E2R-positive breast cancer in obese patients. Estrogen activates PERK in response to the accumulation of unfolded proteins in the endoplasmic reticulum. PERK activates transcription factor STAT3, which increases apoptosis. CLSs-B in obese women with breast cancer are responsible for both increase in local aromatase activity, and enhanced invasiveness and metastasis capacity of cancer cells. Apoptotic hypertrophic fat cells send an 'eat me' signal to macrophages, triggering their own engulfment by ATM. Activated RTKs activate PI3K. PI3K phosphorylates phosphatidylinositol-4,5bisphosphate (PIP2) to generate PIP3. Akt and PDK1 bind to PIP3 at the plasma membrane, and PDK1 phosphorylates the activation loop of Akt. RTK signaling also activates mTORC2 through a currently unknown mechanism, and mTORC2 phosphorylates Akt. Akt activates mTORC1 through multisite phosphorylation of TSC2 within the TSC1-TSC2 complex, and this blocks the ability of TSC2 to act as a GTPase-activating protein (GAP) for Rheb, thereby allowing Rheb-GTP to accumulate. Rheb-GTP activates mTORC1, which phosphorylates downstream targets such as 4E-BP1 and the hydrophobic site on the S6Ks. PDK1 phosphorylates the activation loop on the S6Ks in a reaction independent of PDK1 binding to PIP3. Both mTORC1 and S6K can phosphorylate serine residues on IRS1, which targets IRS1 for degradation, and this serves as a negative feedback mechanism to attenuate PI3K-Akt signaling (insulin resistance pathways). (A) E2R-positive breast cancer specimen; (B) invasive ductal breast cancer, H\&EX400; (C) Diffuse strong nuclear estrogen receptor positivity in carcinoma cells. 4E-BP1, elF4E-binding protein-1; Akt, serine/threonine kinase; ATM, adipose tissue macrophage; BC, breast carcinogenesis pathway; Bcl-2, B-cell lymphoma 2 protein; CDK2, cyclin-dependent kinase 2; C-EBP- $\alpha$, CCAAT/enhancer-binding protein- $\alpha$; CLS-B, crown-like structure in breast adipose tissue; c-Myc, Myc proto-oncogene protein; COX2, cyclooxygenase-2; E2R, estrogen receptor; ERK, extracellular signal-related kinase; FASN, fatty acid synthase; GTBRheb, GTPase-activating protein (GAP) for Ras-related small G protein; HIF-1 $\alpha$, hypoxia-inducible factor-1 $\alpha$; IGF1, insulin-like growth factor-1; IKK 3 , inhibitor kappa B kinase- $\beta$; IL-1, interleukin-1; IL-6, interleukin-6; IL-8, interleukin-8; IRS-1, insulin receptor substrate-1; elF4E, eukaryotic initiation factor 4E; LOX, lipoxygenases; LTB4, leukotriene B4; Itb4r1, leukotriene B4-G protein-coupled receptor; MAPK, mitogen-activated protein kinase; mTORC1, mammalian target of rapamycin complex 1; NFkB, nuclear factor-kappa B; p450-CYP19, aromatase cytochrome P450, product of the CYP19 gene; PDK1, phosphoinositide-dependent kinase-1; PERK, protein kinase RNA-like endoplasmic reticulum kinase; pERK1/2, phosphorylated ERK1-2; PI3K, phosphatidylinositol 3-kinase; PIP3, phosphatidylinositol-3,4,5-trisphosphate; PPAR- $\gamma$, peroxisome proliferatoractivated receptor $\gamma$; RTK, receptor tyrosine kinase; S6K, ribosomal protein S6 kinase-1; SIRT1, silent information regulator-1; STAT3, signal transducer and activator transcription 3; TNF- $\alpha$, tumor necrosis factor- $\alpha$; TSC1, hamartin; TSC2, tuberin.

downregulation of mTORC1 signaling (Liu et al. 2014). Obesity-induced insulin resistance in breast cancer depends on chronic activation of mTORC1. However, inactivation of mTORC1 due to dissociation of Raptor causes elevated IL-6 production, activation of STAT3 and enhanced tumor growth rate (Umemura et al. 2014). The mRNA expression of Raptor is higher in tumors compared with normal tissues. Furthermore, the expression of Raptor is associated with a higher tumor grade (Wazir et al. 2013).
Following the estrogen stimulation, E2R $\alpha$ binds to Raptor and obliges it to translocate to the nucleus. Estrogenregulated interaction between mTORC1 and $\mathrm{E} 2 \mathrm{R} \alpha$, besides the Raptor translocation into the nucleus, causes phosphorylation of E2R $\alpha$ on S104/106. It is believed that the crosstalk between E2R $\alpha$ and PI3K/Akt/mTORC1 signaling ensures the strong activation of oncogenic signaling in E2R $\alpha$-positive breast cancer cells (Alayev et al. 2016). Upstream regulators of mTORC1, TSC1 and 
TSC2 promotes PI3K signaling by suppressing ribosomal protein S6 kinase 1 (p70S6 kinase; S6K). These two tumor suppressor genes, TSC1 and TSC2, function as a guanosine triphosphatase (GTPase)-activating protein (GAP) for the Ras homolog enriched in brain (Rheb) GTPase. The GTPbound form of Rheb directly interacts with mTORC1 and strongly stimulates its kinase activity (Laplante \& Sabatini 2012). mTORC1 activation occurs on the surface of the lysosomal membrane in response to amino acid, whereas the 5' adenosine monophosphate-activated protein kinase (AMPK)-dependent activation of TSC2 and phosphorylation of Raptor reduce mTORC1 signaling (Mihaylova \& Shaw 2011, Bar-Peled et al. 2013). Increased mTORC1 signaling is implicated in obesity. Activation of mTORC1 is not only required for the differentiation of adipocytes, but also promotes carcinogenesis by inhibiting physiological protein turnover via autophagy (Bell et al. 2000, Nazio et al. 2013). Constitutive mTORC1 activation in myeloid cells inhibits developing high-fat diet-induced obesity by promoting macrophage polarization to M2. Additionally, TSC1 deletion increases M2 macrophage polarization together with the mRNA levels of fatty acidbinding protein 4 and PPAR $\gamma$, in an mTORC1-dependent manner (Paschoal et al. 2018). Adipocyte-specific TSC1 deletion reduces visceral fat mass, as well as adipocyte number and diameter associated with increased lipolysis. Furthermore, mitochondrial oxidative activity, fatty acid oxidation and the expression of PPAR $\gamma$ coactivator (PGC)$1 \alpha$ and PPAR $\alpha$ in both visceral and subcutaneous fat adipocyte are increased via TSC1 deletion (Paschoal et al. 2018). In human breast cancer, E2R induces the expression of IGF-1R, insulin receptor substrate 1 (IRS-1) and IRS-2. IGF-1R/insulin receptor kinase activity is required for feedback activation of PI3K/AKT during the inhibition of mTORC1. E2R-mediated nongenomic signaling via IGF-1R/insulin receptor drives PI3K/AKT activation in response to mTORC1 inhibition (Yang et al. 2018). In fact, oncogenic activation of mTOR signaling induces cancer cell growth. The deregulation of protein synthesis downstream of mTORC1 at the level of eukaryotic translation initiation factor 4E (eIF4E)-binding protein 1 (4E-BP1)/eIF4E plays a central role in tumor formation. eiF4E may affect carcinogenesis by promoting the translation of specific mRNAs coding for pro-oncogenic proteins (Laplante \& Sabatini 2012). Increase in de novo lipid synthesis is a hallmark of proliferating cancer cells. Crosstalk between cancer cells and fatty acid synthase (FASN), which is a key lipogenic enzyme catalyzing the terminal steps in the de novo biogenesis of fatty acids, indicates the oncogenic nature of FASN-driven lipogenesis
(Menendez \& Lupu 2007). mTORC1 controls the synthesis of lipids required for proliferating cancer cells to generate own membranes (Laplante \& Sabatini 2009). PI3K signaling promotes the activation of the pro-lipogenic factor sterol regulatory element-binding transcription factor 1 (SREBP1), however, mTORC1 is necessary for oncogenic/growth factor signaling to SREBP1 (Düvel et al. 2010).

Both genomic and nongenomic actions of estrogen play pivotal roles in estrogen-induced cancer cell proliferation and survival (Alexaki et al. 2004). The biological actions of estrogen are mediated by both genomic transcriptional effects in the nucleus and nongenomic actions via E2R $\alpha$. The nongenomic effects of estrogen can lead to the rapid activation of six different groups of signaling molecules; (1) IGF-1R/insulin receptor complex, epidermal growth factor receptor (EGFR), Src, PI3K and mitogen-activated protein kinase kinase (MEK), (2) p21ras and Raf-1, (3) MAPK and Akt, (4) protein kinase C, (5) release of nitric oxide and stimulation of prolactin secretion and (6) alteration of calcium and Maxi-K channels (Yee \& Lee 2000, Adams et al. 2004, Cheskis 2004). Thus, PI3K/Akt and MAPK/ERK1/2 signaling pathways are involved in IGF-1-induced VEGF-C upregulation, and they undertake important roles in lymphatic metastasis in breast cancer (Zhu et al. 2011). Interestingly, both IGF-1R and EGFR initiate activation of MAPK and Akt cascades downstream signaling pathways (Adams et al. 2004). Furthermore, E2R promotes the transcription of genes encoding growth factor receptor tyrosine kinases (RTKs), ligands and signaling adaptors, including IRS-1 and its activator, IGF-1R (Adams et al. 2004). Therefore, crosstalk between IGF- and E2Rsignaling pathways results in synergistic growth. Estrogen enhances IGF signaling by inducing expression of three key IGF regulatory molecules, which include the IGF-1R and its downstream signaling molecules, IRS-1 and IRS-2. Estrogen induction of IGF-R1 and IRS expression results in enhanced tyrosine phosphorylation of IRS-1 after IGF-1 stimulation. This process is followed by augmented MAPK activation. IGF molecules are critical regulators of estrogenmediated growth and breast cancer cells (Lee et al. 1999). Meanwhile, IRS-2 plays an important role in the crosstalk between progesterone and the IGFs in PR-positive breast cancer cells (Cui et al. 2003). Combination of PI3K/ AKT/TORC1 inhibitors with RTK inhibitors provides an optimal suppression on breast cancer growth (Miller et al. 2011). Eventually, the extensive crosstalk between the E2R and PI3K/AKT/mTORC1 pathways provides rationale to target these pathways in $\mathrm{E} 2 \mathrm{R} \alpha$-positive breast cancer (Yang et al. 2018). TSC1/2 conducts several upstream 
signals that influence mTORC1 including IGF1. The effector kinases of these pathways, protein kinase B (Akt), ERK1/2 and ribosomal S6 kinase (RSK1), inactivate TSC1/ TSC2 complex by phosphorylation and thus mTORC1 is activated (Ma et al. 2005, Laplante \& Sabatini 2012). TSC2 is inactivated by Akt-dependent phosphorylation, which destabilizes TSC2 and disrupts its interaction with TSC1 (Inoki et al. 2002). However, in the state of lacking the TSC1-TSC2 complex, Akt signaling is inhibited due to constitutive activation of mTORC1, at large (Huang \& Manning 2009). Aberrant phosphorylation and inhibition of the TSC1/TSC2 complex, and subsequent increased activity of mTOR and/or S6K1 contribute to tumorigenesis caused by mutations that activate the PI3K-Akt pathway. Upon activation of PI3K, TSC1 is phosphorylated on consensus recognition sites for PI3K-dependent serine/ threonine kinases (Manning et al. 2002). ERK-dependent phosphorylation leads to TSC1-TSC2 dissociation and markedly impairs TSC2 ability to inhibit mTOR signaling, cell proliferation and oncogenic transformation (Ma et al. 2005).

mTOR plays a central role in the control of cell growth and proliferation through phosphorylation of its effector molecules, 4E-BP1 and S6K1. Activation of this pathway occurs in response to growth factors, amino acids and nutrients, leading to mRNA translation and ribosome biogenesis (Hay \& Sonenberg 2004). When the TSC1/TSC2 complex genes are inhibited, excessive mTOR activity causes uncontrolled atypical cell proliferation and tumor formation. TSC1 in carriers is more sensitive to the low levels of circulating estrogens in postmenopausal women (Mehta et al. 2011). In premenopausal women, E2R binding to the TSC1 is unlimited due to higher estrogen circulating levels in comparison to postmenopausal women (Mehta et al. 2011). Considering the human breast cancer tissues, TSC1 genes are aberrantly expressed and their promoters are found in methylated form in breast tumor cells. Therefore, the expression of TSC1 shows poor prognosis in patients with breast cancer (Jiang et al. 2005). On the one hand, loss of the TSC1/TSC2 complex genes leads to activation of mTOR and downstream signaling elements. Increase in mTOR activity results in the breast tumor formation as well as severe insulin/IGF-1 resistance at the cellular level. On the other hand, loss of TSC1/TSC2 in human tumors causes endoplasmic reticulum (ER) stress and activates the unfolded protein response (UPR). Eventually, ER stress plays a significant role in the mTORmediated negative feedback inhibition of insulin action and increases the vulnerability to apoptosis (Ozcan et al. 2008).
As previously mentioned, TNF- $\alpha$ is one of the important factors that link obesity-derived chronic inflammation with insulin resistance. In this event, initial activation of mTOR signaling pathway suppresses insulin sensitivity through serine phosphorylation. Subsequently the inhibition of IRS-1 by mTOR and its downstream effector S6K1 contribute to the insulin resistance. TNFo-inhibitor of nuclear factor kappa-B (IKK $\beta$ )-mediated inactivation of TSC1 not only results in increased phosphorylation of IRS-1 at serine 307 and serine 636/639, but also impairs insulin-induced glucose uptake, tyrosine phosphorylation of IRS1 and the association between IRS-1 and PI3K p85 (Lee et al. 2008). TNF $\alpha$, IL-1, IL-6 and IL-8 enhance cell proliferation, cell survival, cell migration and tumor angiogenesis, thereby promoting tumor development. The TNF $\alpha /$ IKK $\beta$ signaling pathway has been suggested to link inflammation to cancer pathogenesis and evasion of apoptosis (Greten et al. 2004, Karin \& Greten 2005).

Furthermore, many cancer-promoting kinases have been identified as regulators of mTOR activity through phosphorylation and inactivation of the TSC1/TSC2 complex. TAMs-derived tumor-promoting factors are the important signaling molecules in tumor development. IKK $\beta$ activates the mTOR pathway and promotes tumor angiogenesis through inactivation of the TSC1/TSC2 complex by phosphorylating TSC1 (Lee \& Hung 2007). Accordingly, the accumulation of M2 phenotype TAMs promotes tumor angiogenesis. The mTOR pathway is a critical element in the regulation of monocyte differentiation to TAMs. Rapamycin causes the monocytes to differentiate into M1 macrophages releasing more IL-12 and less IL-10, whereas TSC2 suppression causes the monocytes to differentiate into $\mathrm{M} 2$ macrophages releasing less IL-12 and more IL-10. The TSC2-mTOR pathway is a key determinant in the differentiation of monocytes into M2 phenotype (Chen et al. 2012). Although rapamycin does not affect the increase in body weight and adiposity, it exacerbates adipose tissue inflammation that is induced by high-fat diet. Increase in adipose tissue inflammation emerges with the increase in the adipose tissue M1 macrophages, activated cytotoxic $\mathrm{T}$ lymphocytes and mRNA levels of pro-inflammatory molecules. mTORC1 inhibition induces phosphorylation of NF-кB p65 and spontaneous polarization of macrophages to a proinflammatory M1 profile, while decreasing M2 polarization. These findings indicate that mTORC1 activity is an important determinant of adipose tissue inflammatory profile and macrophage polarization (Paschoal et al. 2017). Hence, mTORC1 is strongly activated in obesity. The disruption of mTORC1 signaling in macrophages 
protects against inflammation and insulin resistance by inhibiting high-fat diet-induced serine/threonine-protein kinase/endoribonuclease inositol-requiring enzyme $1 \alpha$ (IRE1 $\alpha$ )/c-Jun N-terminal kinase (JNK)/NF-kB pathway. In this respect, macrophage mTORC1 regulates adipose tissue inflammation and insulin sensitivity (Jiang et al. 2014). In contrast, adipocyte-specific deletion of mTOR causes insulin resistance. Additionally, mTOR is required for adipocyte differentiation in vivo, however, activation of PPAR $\gamma$ may provide the differentiation of the mTORdeficient adipocytes (Shan et al. 2016). Consequently, activation of the macrophage mTORC1 signaling pathway suppresses lipolysis, stimulates lipogenesis and promotes ectopic lipid accumulation in obesity (Chakrabarti et al. 2010). Whereas, inhibition of macrophage mTORC1 promotes triacylglycerol lipolysis and release of FFAs, blocks adipogenesis and reduces hypertrophic fat cells (Chakrabarti et al. 2010, Soliman 2011).

\section{Insulin resistance}

M2 macrophages sustain insulin sensitivity by secreting IL-4 and IL-10, while M1 macrophages induce insulin resistance through the secretion of pro-inflammatory cytokines, such as TNF- $\alpha$, in obesity (Tateya et al. 2013). Progression of obesity increasingly induces a phenotypic switch from the M2 macrophages to the M1 macrophages. Hence pro-inflammatory CD11c+ M1 macrophage accumulation is a marker of insulin resistance in human obesity (Wentworth et al. 2010). Thus, the enhanced macrophage-adipocyte crosstalk in obesity disrupts insulin action in adipocytes. Macrophage-secreted factors block insulin action in adipocytes via downregulation of glucose transporter 4 (GLUT4) and IRS-1, leading to a decrease in Akt phosphorylation and impaired insulinstimulated GLUT4 translocation to the plasma membrane (Lumeng et al. 2007b). Furthermore, macrophage-derived IL-1 $\beta$ significantly provokes the development of obesityassociated insulin resistance by inhibiting insulin signal transduction in adipocytes (Bing 2015). Adiposityrelated leptin secretion promotes breast cancer growth directly not only by increasing estrogen secretion, but also by enhancing activity of insulin-signaling pathways (Schmidt et al. 2015). Compared with normal breast tissue, breast tumors express higher levels of insulin receptor and exhibit a greater sensitivity to insulin (Frittitta et al. 1993). In contrast to peripheral insulin resistance in obesity, obese breast adipose tissue may remain insulin sensitive (Vague et al. 1986, Widjaja et al. 1997, Schelbert 2009, Lumeng \& Saltiel 2011). The activation of apoptosis-related proteins inhibits autophagy by degrading autophagy-related proteins (Song et al. 2017). In fact, overexpression of tumor suppressor phosphatase and tensin homolog (PTEN) (dual protein and phosphoinositide phosphatase), which hydrolyzes PtdIns(3,4)P2 and PtdIns(3,4,5)P3, stimulates autophagy. PTEN negatively controls the PI3K/Akt signaling pathway (Arico et al. 2001). In contrast, insulin promotes Akt signaling through 3-phosphoinositidedependent protein kinase 1 (PDK1) by increasing PtdIns3K activity, and inhibits autophagy (Yang \& Klionsky 2010). Activation of this pathway, by expressing an active form of PKB, or expressing a constitutively active form of PDK1, has an inhibitory effect on autophagy. The activation of PI3K-mTORC1 signaling in cancer cells strongly inhibits autophagy (Arico et al. 2001, Meijer \& Codogno 2004).

Since chronic hyperinsulinemia changes insulin stimulation of IGF-1 production and suppression of insulin-like growth factor binding protein-1 (IGFBP-1) and IGFBP-2 production, free IGF-1 concentrations are higher in obese subjects than in normal controls. Despite the positive correlation between total IGF-1 and insulin, there is negative correlation between free IGF-1 and IGFBP-1 (Nam et al. 1997). Chronic hyperinsulinemia-associated decreased concentrations of IGFBP-1 and IGFBP-2 cause elevation of IGF-1 and provokes concomitant tumor formation (Renehan et al. 2006). Indeed, insulin, IGF-1 and IGF-2 have been identified as tumor promoters. IGF-2 induction of the aryl hydrocarbon receptor (AHR) promotes the expression of cyclin D1 and the proliferation of human E2R $\alpha$-positive breast cancer cells (Tomblin \& Salisbury 2014). By contrast, AHR ligands inhibit the proliferative effects of IGF-2 in human E2R $\alpha$ expressing breast cancer cells (Salisbury et al. 2013). Although there is a significant positive correlation between intratumoral AHR and aromatase status, AHR exerts contradictory effects on estrogen action in breast carcinoma cells (Saito et al. 2017). Higher expression of the AHR is significantly associated with increased overall survival and distant metastasis-free survival in E2R $\alpha$-positive breast cancers. Furthermore, raloxifene, which is a selective estrogen receptor modulator, is used for prevention of E2R $\alpha$ positive postmenopausal breast cancer, as an AHR activator (O'Donnell et al. 2014). Recently, PI3K/Akt/ mTOR signaling pathway activation has frequently been observed in E2R $\alpha$-positive breast cancers. The activation of this pathway is associated with increased cell growth, and its overexpression indicates a poor prognosis (Sharma et al. 2017, Bahrami et al. 2018). Simultaneous, expression and activation of the Ras/Raf/MAPK pathway plays a key role in breast cancer cell growth and spreading of the 
tumor cells to distant organs (Chen et al. 2015, Adamczyk et al. 2017). However, some fundamental questions remain unresolved, including the relative importance or functions of the two major signal transduction pathways, PI3K/Akt/mTOR and Ras/Raf/MAPK, that are activated by the IGF-1/IGF-1R axis.

Tyrosine phosphorylation of IRSs and She (Src homology 2 (SH2)-domain-containing and collagen) protein initiate signaling via canonical PI3K/Akt and Ras/MAP kinase pathways. These metabolic pathways together mediate insulin and IGFs signal transduction (Siddle 2011). Activation of insulin receptor signaling due to elevated insulin levels in obesity increases protein synthesis as well as promotes differentiation and growth (Taniguchi et al. 2006). Hyperinsulinemia induces breast cancer progression by two different mechanisms. First, insulin-stimulated leptin expression is associated with increased activation of the leptin gene promoter. Second, hyperinsulinemia in combination with increased insulin receptor expression in tumor tissues results in stimulation of AKT/mTOR signaling and inactivation of AMPK, which leads to the acceleration of tumor growth (Bartella et al. 2008, Kim et al. 2015).

mTORC1-activated S6K1 directly phosphorylates the IRS-1, which promotes IRS-1 degradation and reduces the ability of growth factors to signal downstream of RTK (Harrington et al. 2004). TSC1 and TSC2 promote PI3K signaling and convey insulin signaling to PI3K by restraining the activity of S6K. Similarly, TSC1-2 promotes IGF signaling to PI3K by repressing a negative feedback from mTOR/S6K to the adaptor molecule IRS-1. When S6K is activated, IRS functions are inhibited, via repression of IRS-1 gene expression and phosphorylation of IRS-1. Thereby, S6K-dependent inactivation of IRS- 1 and IRS- 2 is prevented (Harrington et al. 2004, Laplante \& Sabatini 2012). Activation of mTOR/S6K1 signaling has been shown to contribute to the development of insulin resistance. Indeed, increased IRS-1 serine phosphorylation reduces the activity of IRS1, thereby impairs PI3K/AKT signaling and increases insulin resistance (Draznin 2006). TSC2 seems to be the critical target of Akt in mediating growth signals for the insulin-signaling pathway (Potter et al. 2002). The serine/threonine-protein kinase, $\mathrm{PKB}$, which is a key mediator of insulin signaling plays a major role in cancer progression by stimulating cell proliferation and inhibiting apoptosis (Lawlor \& Alessi 2001). However, the absence of TSC1-2 complex function leads to failure in insulin's ability to activate PI3K. In the state of TSC1-2 dysfunction, IGFs cannot activate PI3K, because
S6K inactivates the adaptor proteins IRS-1 and IRS-2 (Harrington et al. 2004).

In fact, the PI3K/mTOR pathway is natively activated as a checkpoint for nutrient/hormonal cell signaling. There is a strong positive association between the risk of breast cancer and fasting insulin levels in postmenopausal women. Breast cancer incidence rates are 2.4-fold greater among those with the highest fasting insulin level. The association between BMI and the risk of breast cancer is attenuated more by controlling the insulin level than by controlling the estradiol level (Gunter et al. 2009). The binding of insulin to the insulin receptor activates the MAPK and PI3K pathways, all leading to an increase in malignant cell proliferation (Antoine et al. 1998). These findings suggest that, breast cancer cells have functional insulin receptors that regulate cell proliferation. The effect of insulin is greater in breast cancer cells in comparison to nonmalignant breast cells. In these cells, insulin is active via both its own receptor and the IGF-1R (Milazzo et al. 1992). In this respect, type 2 diabetes accelerates the development of mammary gland carcinogenesis. The insulin receptor and/or the IGF-1R are major mediators of these effects (Novosyadlyy et al. 2010). Discoidin domain receptors (DDR1 and DDR2) are candidate molecular partners of insulin receptor. In breast cancer cells, IGF-1 stimulation induces tyrosine phosphorylation of DDR1, which is accompanied by increased association of the DDR1-IGF-1R receptor complex. DDR1-IGF-1R functional crosstalk may play a role in cancer progression (Malaguarnera et al. 2015). The crosstalk between the IGF-1 and DDR1 may have important implications in development and progression of cancer. In breast cancer cells, exposure to IGF-1 induces significant upregulation of DDR1 protein. DDR1 upregulation is dependent upon the activation of the PI3K/AKT pathway. The correlation between DDR1 and insulin receptor raises the possibility that insulin resistance and compensatory hyperinsulinemia may enhance DDR1 in malignant mammary tissue. In breast cancer cells, AKT/miR-199a-5p/DDR1 pathway plays an important role in modulating biological responses of IGFs (Matà et al. 2016).

Insulin and estradiol can act in concert to promote cell cycle progression in breast cancer cells. Estrogen significantly increases both mitogens c-Myc and cyclin D1 protein expressions, whereas insulin predominantly increases cyclin D1 levels. Eventually, ectopic expression of c-Myc or cyclin D1 in breast cancer tissue increases cell cycle progression (Mawson et al. 2005). Breast cancer becomes a lethal disease, when it metastasizes and proliferates at distant sites of the body. Enhanced IRS-2 
signaling is not only correlated with increased metastatic potential of breast cancer, but also with enhanced IGF1-induced malignant cell proliferation in lymph nodes (Jackson et al. 2001). Signaling through the IGF-1R is an integral requirement for estrogen-dependent postconfluent proliferation and focus formation in human breast cancer (Bradley et al. 2008). Many recent studies showed that insulin plays an important role in breast carcinogenesis via the extensive crosstalk that occurs between the insulin-IGF and the estrogen-signaling pathways in breast tissue.

\section{ER stress}

Under conditions where more protein synthesis is required, such as during insulin and IGF signaling, early activation of type I transmembrane kinase protein kinase RNA-like ER kinase (PERK) can lead to interruption of protein synthesis and increase the activity of IRE1 kinase. Thereby, insulin receptor signaling can be blocked (Park et al. 2010). ER stress is an important factor accompanying obesity. In this regard, the amount of newly synthesized proteins entering the ER is under negative regulation of the PERK activity, which is ER stress-responsive eIF2 $\alpha$ kinase. PERK is activated by unfolded protein stress in the ER lumen and inhibits new protein synthesis by the phosphorylation of translation initiation factor, eIF2 $\alpha$ (Ron \& Harding 2012). PERK/activating transcription factor 4 (ATF4)-, IRE1 $\alpha-$, ATF6- and $\mathrm{Ca}^{2+}$-signaling pathways induced by ER stress may cause either the initiation of autophagy or apoptosis. However, there is a complex relationship between autophagy and apoptosis. Autophagy can not only block the induction of apoptosis by inhibiting the activation of apoptosisassociated caspase, but also can induce apoptosis (Song et al. 2017). Autophagy-defective cells accumulate protein aggregates, damaged mitochondria and reactive oxygen species, which are believed to promote DNA damage and tumorigenesis (Laplante \& Sabatini 2012).

Nevertheless, PERK is critical to convey stress signals from the ER to the nucleus with multiple stress-responsive transcription factors (Fan et al. 2018). Estrogen significantly suppresses NF- $\mathrm{kB}$ activation in early phase. Thus, it completely blocks TNF- $\alpha$-induced activation of NF-кB. However, PERK, as a stress sensor of UPR, plays an essential role in the late activation of NF- $\mathrm{kB}$ by estrogen. Inhibition of PERK activity completely blocks the DNA binding of both STAT3 and NF-kB, thereby prevents the induction of NF-кB-dependent genes and estrogen-induced apoptosis (Fan et al. 2018). The decline in estrogen levels during the postmenopausal period is associated with increased cytokine production and inflammation. In fact, estrogens exert anti-inflammatory effect by repressing TNF- $\alpha$. This process reverses the ligand-independent activation by $\mathrm{E} 2 \mathrm{R} \alpha$ and the stimulatory actions of c-jun-NF-kB-cAMP response element-binding protein (CREB)-binding protein (CBP) pathway (Cvoro et al. 2006). In the case of increased estrogen synthesis, estrogen enhances the expression of the adipogenic transcription factor, C/EBP- $\beta$, which is responsible for the suppression of NF- $\mathrm{kB}$ activation by estrogen (Fan et al. 2018). In postmenopausal period, TNF- $\alpha$ accumulates unliganded E2R along with heat shock protein 90 (Hsp90) to the TNF- $\alpha$ promoter. Thus, E2R $\alpha$ acts as a TNF- $\alpha$-activated coactivator and represents a unique transcriptional activity for E2R (Cvoro et al. 2006). Under ER stress, PERK can activate NF-кB-DNA binding through decreasing levels of inhibitor kappa-B-alpha (IKB $\alpha$ ). In this manner, NF-KB activation correlates with decreased levels of the I $\mathrm{KB} \alpha$ protein (Deng et al. 2004). Briefly, estrogen activates the sensors of the UPR, IRE1 $\alpha$ and PERK in breast cancer cells. Estrogen also dramatically increases reactive oxygen species production and upregulates expression of heme oxygenase (HMOX1), an indicator of oxidative stress, along with the central energy sensor kinase AMPK (PRKAA2) (Fan et al. 2013).

Obesity-related ER stress simultaneously leads to suppression of insulin receptor signaling through hyperactivation of JNK and subsequent serine phosphorylation of IRS-1 (Ozcan et al. 2004). Obesity and insulin resistance indicate the failure of the ER's adaptive capacity. In this manner, activation of the UPR during the ER stress is associated with many different inflammatory and stress signaling pathways (Hotamisligil 2010). Indeed, one of the identified pathways leading to the development of ER stress in obesity is the mTOR pathway (Ozcan et al. 2008).

\section{SIRT1-mTOR crosstalk}

The high-fat diet decreases the expression of SIRT1 and elevates Akt2 and IL-6 expression (Liu et al. 2016). However, SIRT1 significantly decreases the levels of Raptor and inactivates mTORC1 signal by interacting with Akt2. SIRT1-mediated inhibition of mTORC1 enhances lipolysis. While FFAs increase in plasma, adipogenesis is inhibited (Liu et al. 2016). In high-fat diet-induced obesity, phosphorylation of Akt in macrophages could activate mTOR signal and then leads to inflammation and insulin resistance (Jiang et al. 2014). However, macrophage SIRT1 activators enhance systemic insulin 
sensitivity, by decreasing adipose tissue inflammation, and M1 macrophage accumulation (Yoshizaki et al. 2010). In parallel with macrophages, activation of SIRT1 in adipocyte can reduce TNF- $\alpha$-induced insulin resistance and inflammation (Yoshizaki et al. 2009). Adipocyte SIRT1 controls systemic glucose homeostasis and insulin sensitivity via the crosstalk with adiposeresident macrophages (Hui et al. 2017). Consequently, it is evidenced that the interaction between SIRT1 and Akt2 is important in the mTOR/S6K1 pathway-mediated progression of adipose tissue inflammation in obesity (Liu et al. 2016).

The deleted breast cancer-1 (DBC1) is a nuclear protein, however it is absent in human breast cancer cells. DBC1 is employed as a native inhibitor of SIRT1 in human cells. DBC1-mediated repression of SIRT1 leads to increasing levels of p53 acetylation and upregulation of p53mediated function (Zhao et al. 2008). Indeed, other SIRT1 inhibitors like DBC1 show anticancer activity through p53 acetylation in human breast cancer cells (Park et al. 2016). SIRT1 activity is positively regulated by the protein kinases, PKA and AMPK. However, AMPK-dependent PKA activation leads to the dissociation of SIRT1 from its endogenous inhibitor DBC1 and free SIRT1 increases. Thereby, SIRT1 is activated by cAMP/PKA/AMPK/DBC1dependent pathway (Nin et al. 2012). Free DBC1 provokes NF-кB-induced pro-inflammatory activity in differentiated adipocytes of obese individuals (Park et al. 2013, MorenoNavarrete et al. 2015). In high-fat diet, decreased SIRT1 activity and increased interaction with DBC1 is observed (Escande et al. 2010). Conversely, genetic deletion of DBC1 unexpectedly results in obesity-related insulin resistance. In addition, DBC1 depletion in adipocytes activates SIRT1dependent function of stearoyl-coenzyme A desaturase 1 (Scd1), increasing plasma and tissue levels of unsaturated fatty acids (Qiang et al. 2015). Increased expression of SIRT1 in hormone receptor-positive breast cancer is significantly correlated with lower risks of axillary lymph node metastasis (LNM), whereas in estrogen-independent high-grade breast cancer excessive SIRT1 expression is more frequently observed in patients with LNM-positive (Chung et al. 2015). It is well-known that the enzymatic activity of aromatase is critical for the growth of estrogendependent breast cancers. However, SIRT1 inactivation suppresses E2R $\alpha$ signaling, thereby inhibits estrogen/ E2Ro-induced breast cancer growth by triggering apoptosis (Yao et al. 2010, Elangovan et al. 2011). Since SIRT1 is a positive regulator of aromatase mRNA levels, inhibitors of SIRT1 decrease the mRNA-protein levels of aromatase. Thus, SIRT1 controls aromatase expression by targeting nonhistone proteins or transcription factors that activates CYP19A1. SIRT1-specific inhibitors cause a reduction in aromatase levels (Holloway et al. 2013). In this context, transcriptional control of CYP19A1 by SIRT1 is achieved through PGC-1 $\alpha$, E2R $\alpha$ and $\beta$-catenin (Rodgers et al. 2005, Holloway et al. 2010, Wilson et al. 2010). In fact, SIRT1 localizes to the PII/I.3 and PI.4 promoters in breast cancer cells and regulates E2R $\alpha$ acetylation and protein levels. Therefore, SIRT1 is overexpressed by 2.6-fold in invasive ductal carcinoma cells in comparison to normal breast tissue (Holloway et al. 2013). In addition to reduction in aromatase activity, inhibition of SIRT1 causes the suppression of estrogen receptor signaling (Yao et al. 2010). In contrast, increased SIRT1 mRNA and protein levels ameliorate inflammation and improve insulin sensitivity, whereas SIRT1 deficiency intensifies adipose tissue inflammation and insulin resistance in obesity (Peng et al. 2017). There are two potential mechanisms by which E2R target genes are regulated by p53. First, protein-protein interaction between E2R $\alpha$ and p53 can lead to alterations in E2R target gene expression (Liu et al. 1999). Second, E2R $\alpha$ regulates some p53 target genes which contain estrogen response element (ERE) sites (Angeloni et al. 2004). SIRT1 promotes cell survival by deacetylating, and thereby negatively regulating the activity of important tumor suppressors such as p53. Therefore, the role of SIRT1 in breast cancer has been controversial in obesity (Han et al. 2013). SIRT1 expression induced by E2R $\alpha$ activates antioxidant and pro-survival genes in the breast cancer cells. SIRT1 inactivation eliminates estrogen/E2R $\alpha$ induced cell growth and tumor development by triggering apoptosis (Elangovan et al. 2011). Unlike full length E2R $\alpha$ and E2R $\alpha 46, \mathrm{E} 2 \mathrm{R} \alpha 36$ is localized in the cytoplasm and the plasma membrane, where it is thought to mediate nongenomic estrogen signaling. Overexpression of E2R $\alpha 36$ is significantly associated with poorer disease-free survival and disease-specific survival in E2R $\alpha 66$-positive patients. E2R $\alpha 66$-positive tumors that also express high levels of E2R 36 are less likely to benefit from tamoxifen treatment (Shi et al. 2009). Tamoxifen has not only been used for the treatment or prevention of recurrence in patients with E2R-positive breast cancers, but also for recurrent breast cancer (Zembutsu 2015). Overexpression of SIRT1 with FOXO1 increases multidrug resistance protein 2 expression, whereas the basal activity of SIRT1 is increased in tamoxifen-resistant breast cancer cells. However, SIRT1 inhibition reduces both the nuclear FOXO1 levels and multidrug resistance protein 2 expression, thereby cytotoxic effects of chemotherapeutics are enhanced in tamoxifen-resistant breast cancer cells (Choi et al. 2013). 
Since SIRT1 is a positive regulator of aromatase activity, aromatase inhibitors are superior to tamoxifen as adjuvant hormonal therapy for postmenopausal E2R-positive breast cancer (Rydén et al. 2016).

\section{Uncoupled respiration and hypoxia}

Decreasing mitochondrial coupling efficiency promotes uncoupled respiration of adipocytes in high-fat dietinduced obesity and increases energy expenditure as well as suppresses energy intake (Fu et al. 2013). In obesity, high level of saturated fatty acids induces adenine nucleotide translocase activity, which leads to the uncoupled respiration. Uncoupled respiration while increasing oxygen consumption causes relative adipocyte hypoxia. Consequently, relative cellular hypoxia due to increased adipocyte oxygen consumption triggers hypoxiainducible factor- $1 \alpha$ (HIF-1 $\alpha$ ) response (Lee et al. 2014). Adipocyte hypertrophy creates poorly oxygenated areas in the human obese adipose tissue (Murdoch et al. 2004). Decreased adipose tissue partial oxygen concentration is paralleled by an increase in the expression and secretion of the chemokine and markers of macrophage infiltration (Pasarica et al. 2009). HIF-1 $\alpha$ stimulates production of the adipocyte-derived chemokines MCP-1 and leukotriene B4 (LTB4), which drive accumulation of pro-inflammatory ATMs (Lee et al. 2014). The LTB4/Ltb4r1 (G protein-coupled receptor) system is a major driver for the inflammation/ insulin resistance syndrome in obesity. Thus, LTB4 promotes migration of monocytes into adipose tissue and directly stimulates macrophage Ltb4r1 to activate intracellular pro-inflammatory pathways (Li et al. 2015). A positive feedback loop containing fatty acid synthase (FASN)/phosphorylated ERK1-2 (p-ERK1-2)/lipoxygenases (5-LOX)/LTB4/FASN provides high proliferative capacity for breast cancer cells ( $\mathrm{Hu}$ et al. 2011). While increased expression of HIF- $1 \alpha$ by adipocytes is associated with the poor prognosis for breast cancer at early stage of obesity, at prolonged hypoxia HIF- $2 \alpha$ expression is an indicator of reduced recurrence-free survival (Helczynska et al. 2008, Rausch et al. 2017). Indeed, in early stage of obesity, overexpression of adipocyte HIF- $1 \alpha$ due to adipose tissue hypoxia mediates the production of reactive oxygen species that activate the NF- $\mathrm{B}$ pathway, induces the expressions of several chemokines and increases the accumulation of ATMs in the adipose tissue (Halberg et al. 2009, Jiang et al. 2011, Lee et al. 2011, 2014). During the later stage of obesity, CLSs also create remarkably hypoxic areas in adipose tissues. Adipose tissue hypoxia induces inflammatory phenotype of M1 ATMs via
HIF-1 $\alpha$-dependent mechanisms, partly (Fujisaka et al. 2013). Therefore, macrophage HIF- $1 \alpha$ links hypoxia and inflammation through the CLSs of obese adipose tissue. Insulin resistance is the result of these sequential series of events in obesity (Takikawa et al. 2016). Conversely, overexpression of macrophage HIF- $2 \alpha$ attenuates adipose tissue inflammation and improves insulin resistance in obese adipocytes (Choe et al. 2014). In this vicious circle, hyperinsulinemia induces HIF- $1 \alpha$ expression, which upregulates oxidative stress in E2R-positive breast cancer cells (Wang et al. 2017). TAMs secrete pro-inflammatory cytokines and chemokines, including TNF- $\alpha$, IL-1, IL-6 and IL-8, to enhance cell proliferation, cell survival and inflammation-mediated tumor angiogenesis and thereby promote tumor progression. TNF- $\alpha$ activates mTORC1 signaling, which is known to induce S6K1 activation and vascular endothelial growth factor (VEGF) production, through phosphorylation and inactivation of TSC1 by IKK $\beta$ in breast cancers. VEGF-regulated angiogenesis is a key factor for metastasis (Lee et al. 2007). Breast cancer is characterized by having a large population of TAMs. Hypoxia in the tumor microenvironment stimulates macrophages to further produce VEGF and suppresses the T-cell immune responses, thus enhancing the evasion of tumor cells and ultimately metastasis (Obeid et al. 2013). As mentioned above, it is thought that hypoxia due to increase in adipocyte diameter and decrease of adipose tissue capillary density are potential causes of the inflammatory changes occurring in obese adipose tissue (Fujisaka et al. 2013, Lee et al. 2014). In addition, the primary source of hypoxia-induced inflammatory cytokine is ATMs in obesity (O'Rourke et al. 2011). Consequently, enhanced macrophage pro-inflammatory cytokine production causes increased inflammatory response in adipocytes. In this respect, hypoxia is a potential factor to initiate pro-inflammatory adipocytemacrophage crosstalk. Furthermore, activation of JNK signaling is critical for the enhancement of fatty acidtriggered inflammatory responses in hypoxia (Snodgrass et al. 2016). In fact, obesity is associated with the type-1 inflammatory responses, which is characterized by IFN$\gamma$ synthesis. IFN- $\gamma$ expression shifts ATMs toward M1 phenotype (Wensveen et al. 2015). Hypoxic adipocytereleased exosomes contain 3- to 4-fold higher amounts of enzymes, which are related to de novo lipogenesis such as acetyl-CoA carboxylase and FASN. Exosomal proteins released from hypoxic adipocytes affect lipogenic activity in neighboring preadipocytes and adipocytes (Sano et al. 2014). IL-4-Akt-mTORC1 pathway acts as a nutrient sensor for the macrophages and control the enzyme, 
which is responsible for acetyl-CoA synthesis. Increase in acetyl-CoA levels changes the profile of M2 macrophages (Covarrubias et al. 2016). Hypoxia induces expression of regulated in development and DNA damage responses 1 (REDD1) gene, which promotes TSC1/2 complex and subsequently inhibits mTORC1 activity. Loss of either TSC1 or TSC2 blocks the effects of hypoxia on mTORC1 (Brugarolas et al. 2004). TNF- $\alpha-I L-10-m T O R C 1-S T A T 3$ signaling pathway is induced by hypoxia in primary human macrophages and may modulate TNF responses during chronic inflammation (Huynh et al. 2016). In this respect, while STAT3 mRNA expression in adipose tissue is positively correlated with IL-10 and adiponectin expression, it is negatively correlated with triglycerides levels. Therefore, IL-10/JAK-STAT3 pathway activity is decreased due to obesity-related hypertriglyceridemia (Liu et al. 2018). PI3K/Akt contributes to hypoxic stressinduced TLR4 expression through the regulation of HIF-1 activation (Kim et al. 2012). Moreover, hypoxia increases the activation of JNK and p38 MAPK signaling in saturated fatty acid-treated macrophages. Hypoxia along with higher concentrations of FFAs exacerbates macrophagemediated inflammation in obesity (Snodgrass et al. 2016).

\section{Conclusion}

Elevated estrogen concentrations in postmenopausal E2R-positive breast cancer patients are largely derived from obese adipose tissue aromatization. Moreover, hyperinsulinemia is an independent risk factor for poor prognosis in breast cancer, and is associated with high levels of leptin and shorter breast cancer-free survival in obesity. Collectively, as obese breast adipocyte is master regulator of tumor growth through leptin-aromatasetumor-associated macrophage axis and SIRT1-adiposeresident macrophage axis, unresolved mechanistic gaps at molecular links of adipocyte-macrophages-tumor cell interactions in obesity-associated breast cancer create difficulties in patient's treatment.

\section{Future perspectives}

The role of SIRT1 in obese patients with breast cancer has been controversial. Inhibition of SIRT1 causes the suppression of estrogen receptor signaling, besides the reduction in aromatase activity. In contrast, increased expression of SIRT1 in E2R $\alpha$-positive breast cancer not only reduces TNF- $\alpha$-induced insulin resistance, but also lowers risks of axillary LNM. Therefore, further investigation is necessary to clarify whether the levels of SIRT1 expression may provide an innovative strategy that may complement or synergize with existing therapies. In addition, the biological evaluations of sirtuin and PI3K/AKT/mTOR pathway inhibitors are still under investigation (Chen 2011, Villalba \& Alcaín 2012, Brufsky 2014, Ciruelos Gil 2014).

A high-fat diet with estrogen deprivation leads to development of insulin resistance, which accelerates distant recurrence and death in patients with breast cancer. Hyperinsulinemia induces breast cancer progression through leptin-dependent mechanisms. Although most of the obese humans are characterized by leptin resistance, anti-estrogen therapy increases serum leptin levels and increases leptin resistance even more in obese postmenopausal breast cancer patients. Thus, excessive leptin correlates significantly with poor prognosis in overall and tamoxifen-treated breast cancer patients (Maffei et al. 1995). Since leptin also enhances aromatase expression in breast cancer cells, suppression of leptin effects may be a novel modality of circumventing resistance to anti-estrogen treatment. 'Anti-leptin receptor antibody treatment' seems to be a rational approach to resolve insulin resistance and anti-estrogen drug resistance in breast cancer (Rios Garcia et al. 2017).

Because of the activity of de novo fatty acid synthesis pathway, breast cancer cells are independent of the extracellular lipids. Acetyl-CoA carboxylase (ACC1) phosphorylation and inhibition are a necessary step in leptin-promoted epithelial-mesenchymal transition (EMT) in breast cancer. Therefore, inhibition of ACC1 increases the metastatic capacity of breast cancer cells. In tumor cells, which are treated with the EMT inducers, leptin and TGF $\beta$, ACC1 phosphorylation increases. In this context, further investigation is necessary regarding the 'anti-leptin receptor antibody' treatment reducing the activity of leptin-ACC1 axis-dependent tumor invasiveness that may complement or synergize with existing therapies (Rios Garcia et al. 2017).

Taken together, evidences suggest that the leptin system and its second messengers might play an important role in breast cancer progression by enhancing estrogen effects via a paracrine pathway, and that might represent a novel target for therapeutic intervention in breast cancer. Although in breast cancer, benefit of anti-IGF/insulinsignaling agents in combination with hormone therapy has not yet been proven, and development of predictive biomarkers and optimal inhibitory strategies of the IGF/insulin pathway activity would yield better clinical outcomes (Yang \& Yee 2012). Leptin resistance increases in SOCS3 expression. While leptin effect is mediated by 
MAPK/ERK1/2-STAT3, SOCS proteins potently regulate the intensity and extent of STAT signals. Therefore, downregulation of STAT3 and STAT5a/b has been suggested as a mechanism of anti-proliferative effects of some anticancer agents in breast cancer cells. Of these, MSM decreases the DNA-binding activities of STAT5b and STAT3 to the target gene promoters (Lim et al. 2012). Therefore, unclarified adipocyte-macrophage-tumor cell interactions in obesity-associated breast cancer create serious handicap, in planning breast cancer treatment modalities.

\section{Declaration of interest}

The authors declare that there is no conflict of interest that could be perceived as prejudicing the impartiality of this review.

\section{Funding}

This research did not receive any specific grant from any funding agency in the public, commercial or not-for-profit sector.

\section{Author contribution statement}

Immunological aspects of adipocyte-macrophage interactions were reviewed by A B Engin, breast cancer-related biochemical pathways in obesity were evaluated by A Engin and histopathological compliance was evaluated by II Gonul.

\section{Acknowledgements}

We are grateful to Professor Barbara Clark, for her kind invitation and suggesting the subject of this review manuscript.

\section{References}

Adamczyk A, Grela-Wojewoda A, Domagała-Haduch M, Ambicka A, Harazin-Lechowska A, Janecka A, Cedrych I, Majchrzyk K, Kruczak A, Ryś J, et al. 2017 Proteins involved in HER2 signalling pathway, their relations and influence on metastasis-free survival in HER2-positive breast cancer patients treated with trastuzumab in adjuvant setting. Journal of Cancer 8 131-139. (https://doi.org/10.7150/jca.16239)

Adams TE, McKern NM \& Ward CW 2004 Signalling by the type 1 insulin-like growth factor receptor: interplay with the epidermal growth factor receptor. Growth Factors 22 89-95. (https://doi.org/10.1 080/08977190410001700998)

Alayev A, Salamon RS, Berger SM, Schwartz NS, Cuesta R, Snyder RB \& Holz MK 2016 mTORC1 directly phosphorylates and activates ER $\alpha$ upon estrogen stimulation. Oncogene 35 3535-3543. (https://doi. org/10.1038/onc.2015.414)

Alexaki V-I, Charalampopoulos I, Kampa M, Vassalou H, Theodoropoulos P, Stathopoulos EN, Hatzoglou A, Gravanis A \& Castanas E 2004 Estrogen exerts neuroprotective effects via membrane estrogen receptors and rapid Akt/NOS activation. FASEB Journal 18 1594-1596. (https://doi.org/10.1096/fj.04-1495fje)

Ali S \& Coombes RC 2000 Estrogen receptor alpha in human breast cancer: occurrence and significance. Journal of Mammary Gland
Biology and Neoplasia 5 271-281. (https://doi. org/10.1023/A:1009594727358)

Angeloni SV, Martin MB, Garcia-Morales P, Castro-Galache MD, Ferragut JA \& Saceda M 2004 Regulation of estrogen receptor-alpha expression by the tumor suppressor gene p53 in MCF-7 cells. Journal of Endocrinology 180 497-504. (https://doi.org/10.1677/ joe.0.1800497)

Antoine PJ, Bertrand F, Auclair M, Magré J, Capeau J \& Cherqui G 1998 Insulin induction of protein kinase $\mathrm{C}$ alpha expression is independent of insulin receptor Tyr1162/1163 residues and involves mitogen-activated protein kinase kinase 1 and sustained activation of nuclear p44MAPK. Endocrinology 139 3133-3142. (https://doi. org/10.1210/endo.139.7.6094)

Arico S, Petiot A, Bauvy C, Dubbelhuis PF, Meijer AJ, Codogno P \& Ogier-Denis E 2001 The tumor suppressor PTEN positively regulates macroautophagy by inhibiting the phosphatidylinositol 3-kinase/ protein kinase B pathway. Journal of Biological Chemistry 276 35243-35246. (https://doi.org/10.1074/jbc.C100319200)

Arner E, Westermark PO, Spalding KL, Britton T, Rydén M, Frisén J, Bernard S \& Arner P 2010 Adipocyte turnover: relevance to human adipose tissue morphology. Diabetes 59 105-109. (https://doi. org/10.2337/db09-0942)

Bahrami A, Khazaei M, Shahidsales S, Hassanian SM, Hasanzadeh M, Maftouh M, Ferns GA \& Avan A 2018 The therapeutic potential of PI3K/Akt/mTOR inhibitors in breast cancer: rational and progress. Journal of Cellular Biochemistry 119 213-222. (https://doi. org/10.1002/jcb.26136)

Bai Y \& Sun Q 2015 Macrophage recruitment in obese adipose tissue. Obesity Reviews 16 127-136. (https://doi.org/10.1111/obr.12242)

Bar-Peled L, Chantranupong L, Cherniack AD, Chen WW, Ottina KA, Grabiner BC, Spear ED, Carter SL, Meyerson M \& Sabatini DM 2013 A tumor suppressor complex with GAP activity for the Rag GTPases that signal amino acid sufficiency to mTORC1. Science $\mathbf{3 4 0}$ 1100-1106. (https://doi.org/10.1126/science.1232044)

Bartella V, Cascio S, Fiorio E, Auriemma A, Russo A \& Surmacz E 2008 Insulin-dependent leptin expression in breast cancer cells. Cancer Research 68 4919-4927. (https://doi.org/10.1158/0008-5472.CAN-080642)

Barton GM \& Kagan JC 2009 A cell biological view of Toll-like receptor function: regulation through compartmentalization. Nature Reviews Immunology 9 535-542. (https://doi.org/10.1038/nri2587)

Bell A, Grunder L \& Sorisky A 2000 Rapamycin inhibits human adipocyte differentiation in primary culture. Obesity Research $\mathbf{8}$ 249-254. (https://doi.org/10.1038/oby.2000.29)

Bing C 2015 Is interleukin-1 $\beta$ a culprit in macrophage-adipocyte crosstalk in obesity? Adipocyte 4 149-152. (https://doi.org/10.4161/21 623945.2014.979661)

Bougaret L, Delort L, Billard H, Le Huede C, Boby C, De la Foye A, Rossary A, Mojallal A, Damour O, Auxenfans C, et al. 2018 Adipocyte/breast cancer cell crosstalk in obesity interferes with the anti-proliferative efficacy of tamoxifen. PLOS ONE 13 e0191571. (https://doi.org/10.1371/journal.pone.0191571)

Boutens L \& Stienstra R 2016 Adipose tissue macrophages: going off track during obesity. Diabetologia 59 879-894. (https://doi. org/10.1007/s00125-016-3904-9)

Boyd NF \& McGuire V 1990 Evidence of association between plasma high-density lipoprotein cholesterol and risk factors for breast cancer. Journal of the National Cancer Institute 82 460-468. (https:// doi.org/10.1093/jnci/82.6.460)

Bradley LM, Gierthy JF \& Pentecost BT 2008 Role of the insulin-like growth factor system on an estrogen-dependent cancer phenotype in the MCF-7 human breast cancer cell line. Journal of Steroid Biochemistry and Molecular Biology 109 185-196. (https://doi. org/10.1016/j.jsbmb.2007.10.006)

Braune J, Weyer U, Hobusch C, Mauer J, Brüning JC, Bechmann I \& Gericke M 2017 IL-6 regulates M2 polarization and local 
proliferation of adipose tissue macrophages in obesity. Journal of Immunology 198 2927-2934. (https://doi.org/10.4049/ jimmunol.1600476)

Brufsky AM 2014 Managing postmenopausal women with hormone receptor-positive advanced breast cancer who progress on endocrine therapies with inhibitors of the PI3K pathway. Breast Journal 20 347-357. (https://doi.org/10.1111/tbj.12278)

Brugarolas J, Lei K, Hurley RL, Manning BD, Reiling JH, Hafen E, Witters LA, Ellisen LW \& Kaelin WG 2004 Regulation of mTOR function in response to hypoxia by REDD1 and the TSC1/TSC2 tumor suppressor complex. Genes and Development 18 2893-2904. (https://doi.org/10.1101/gad.1256804)

Chakrabarti P, English T, Shi J, Smas CM \& Kandror KV 2010 Mammalian target of rapamycin complex 1 suppresses lipolysis, stimulates lipogenesis, and promotes fat storage. Diabetes $\mathbf{5 9}$ 775-781. (https://doi.org/10.2337/db09-1602)

Chen L 2011 Medicinal chemistry of sirtuin inhibitors. Current Medicinal Chemistry 18 1936-1946. (https://doi. org/10.2174/092986711795590057)

Chen W, Ma T, Shen X, Xia X, Xu G, Bai X \& Liang T 2012 Macrophage-induced tumor angiogenesis is regulated by the TSC2mTOR pathway. Cancer Research 72 1363-1372. (https://doi. org/10.1158/0008-5472.CAN-11-2684)

Chen X-Y, Zhou J, Luo L-P, Han B, Li F, Chen J-Y, Zhu Y-F, Chen W \& Yu X-P 2015 Black rice anthocyanins suppress metastasis of breast cancer cells by targeting RAS/RAF/MAPK pathway. BioMed Research International 2015 414250. (https://doi.org/10.1155/2015/414250)

Cheskis BJ 2004 Regulation of cell signalling cascades by steroid hormones. Journal of Cellular Biochemistry 93 20-27. (https://doi. org/10.1002/jcb.20180)

Chlebowski RT, Anderson GL, Gass M, Lane DS, Aragaki AK, Kuller LH, Manson JE, Stefanick ML, Ockene J, Sarto GE, et al. 2010 Estrogen plus progestin and breast cancer incidence and mortality in postmenopausal women. JAMA 304 1684-1692. (https://doi. org/10.1001/jama.2010.1500)

Choe SS, Shin KC, Ka S, Lee YK, Chun J-S \& Kim JB 2014 Macrophage HIF- $2 \alpha$ ameliorates adipose tissue inflammation and insulin resistance in obesity. Diabetes 63 3359-3371. (https://doi. org/10.2337/db13-1965)

Choi H-K, Cho KB, Phuong NTT, Han CY, Han H-K, Hien TT, Choi HS \& Kang KW 2013 SIRT1-mediated FoxO1 deacetylation is essential for multidrug resistance-associated protein 2 expression in tamoxifenresistant breast cancer cells. Molecular Pharmaceutics 10 2517-2527. (https://doi.org/10.1021/mp400287p)

Chung YR, Kim H, Park SY, Park IA, Jang JJ, Choe J-Y, Jung YY, Im S-A, Moon H-G, Lee K-H, et al. 2015 Distinctive role of SIRT1 expression on tumor invasion and metastasis in breast cancer by molecular subtype. Human Pathology 46 1027-1035. (https://doi.org/10.1016/j. humpath.2015.03.015)

Cinti S, Mitchell G, Barbatelli G, Murano I, Ceresi E, Faloia E, Wang S, Fortier M, Greenberg AS \& Obin MS 2005 Adipocyte death defines macrophage localization and function in adipose tissue of obese mice and humans. Journal of Lipid Research 46 2347-2355. (https:// doi.org/10.1194/jlr.M500294-JLR200)

Ciruelos Gil EM 2014 Targeting the PI3K/AKT/mTOR pathway in estrogen receptor-positive breast cancer. Cancer Treatment Reviews $\mathbf{4 0}$ 862-871. (https://doi.org/10.1016/j.ctrv.2014.03.004)

Clément K, Viguerie N, Poitou C, Carette C, Pelloux V, Curat CA, Sicard A, Rome S, Benis A, Zucker J-D, et al. 2004 Weight loss regulates inflammation-related genes in white adipose tissue of obese subjects. FASEB Journal 18 1657-1669. (https://doi.org/10.1096/fj.042204com)

Covarrubias AJ, Aksoylar HI, Yu J, Snyder NW, Worth AJ, Iyer SS, Wang J, Ben-Sahra I, Byles V, Polynne-Stapornkul T, et al. 2016 AktmTORC1 signaling regulates Acly to integrate metabolic input to control of macrophage activation. ELife 5 e11612. (https://doi. org/10.7554/eLife.11612)

Cui X, Lazard Z, Zhang P, Hopp TA \& Lee AV 2003 Progesterone crosstalks with insulin-like growth factor signaling in breast cancer cells via induction of insulin receptor substrate-2. Oncogene 22 6937-6941. (https://doi.org/10.1038/sj.onc.1206803)

Cvoro A, Tzagarakis-Foster C, Tatomer D, Paruthiyil S, Fox MS \& Leitman DC 2006 Distinct roles of unliganded and liganded estrogen receptors in transcriptional repression. Molecular Cell 21 555-564. (https://doi.org/10.1016/j.molcel.2006.01.014)

Dalmas E, Toubal A, Alzaid F, Blazek K, Eames HL, Lebozec K, Pini M, Hainault I, Montastier E, Denis RGP, et al. 2015 Irf5 deficiency in macrophages promotes beneficial adipose tissue expansion and insulin sensitivity during obesity. Nature Medicine 21 610-618. (https://doi.org/10.1038/nm.3829)

Deng J, Lu PD, Zhang Y, Scheuner D, Kaufman RJ, Sonenberg N, Harding HP \& Ron D 2004 Translational repression mediates activation of nuclear factor kappa B by phosphorylated translation initiation factor 2. Molecular and Cellular Biology 24 10161-10168. (https://doi.org/10.1128/MCB.24.23.10161-10168.2004)

Draznin B 2006 Molecular mechanisms of insulin resistance: serine phosphorylation of insulin receptor substrate-1 and increased expression of p85alpha: the two sides of a coin. Diabetes $\mathbf{5 5}$ 2392-2397. (https://doi.org/10.2337/db06-0391)

Duvall E, Wyllie AH \& Morris RG 1985 Macrophage recognition of cells undergoing programmed cell death (apoptosis). Immunology $\mathbf{5 6}$ 351-358.

Düvel K, Yecies JL, Menon S, Raman P, Lipovsky AI, Souza AL, Triantafellow E, Ma Q, Gorski R, Cleaver S, et al. 2010 Activation of a metabolic gene regulatory network downstream of mTOR complex 1. Molecular Cell 39 171-183. (https://doi.org/10.1016/j. molcel.2010.06.022)

Elangovan S, Ramachandran S, Venkatesan N, Ananth S, GnanaPrakasam JP, Martin PM, Browning DD, Schoenlein PV, Prasad PD, Ganapathy V, et al. 2011 SIRT1 is essential for oncogenic signaling by estrogen/estrogen receptor $\alpha$ in breast cancer. Cancer Research $\mathbf{7 1}$ 6654-6664. (https://doi.org/10.1158/0008-5472.CAN-11-1446)

Escande C, Chini CCS, Nin V, Dykhouse KM, Novak CM, Levine J, van Deursen J, Gores GJ, Chen J, Lou Z, et al. 2010 Deleted in breast cancer-1 regulates SIRT1 activity and contributes to high-fat dietinduced liver steatosis in mice. Journal of Clinical Investigation $\mathbf{1 2 0}$ 545-558. (https://doi.org/10.1172/JCI39319)

Fan P, Griffith OL, Agboke FA, Anur P, Zou X, McDaniel RE, Creswell K, Kim SH, Katzenellenbogen JA, Gray JW, et al. 2013 c-Src modulates estrogen-induced stress and apoptosis in estrogen-deprived breast cancer cells. Cancer Research 73 4510-4520. (https://doi. org/10.1158/0008-5472.CAN-12-4152)

Fan P, Tyagi AK, Agboke FA, Mathur R, Pokharel N \& Jordan VC 2018 Modulation of nuclear factor-kappa B activation by the endoplasmic reticulum stress sensor PERK to mediate estrogen-induced apoptosis in breast cancer cells. Cell Death Discovery 4 15. (https://doi. org/10.1038/s41420-017-0012-7)

Franchi L, Eigenbrod T, Muñoz-Planillo R \& Nuñez G 2009 The inflammasome: a caspase-1-activation platform that regulates immune responses and disease pathogenesis. Nature Immunology 10 241-247. (https://doi.org/10.1038/ni.1703)

Frittitta L, Vigneri R, Papa V, Goldfine ID, Grasso G \& Trischitta V 1993 Structural and functional studies of insulin receptors in human breast cancer. Breast Cancer Research and Treatment 25 73-82. (https:// doi.org/10.1007/BF00662403)

Fu Y-Y, Zhang M, Turner N, Zhang L-N, Dong T-C, Gu M, Leslie SJ, Li JY, Nan F-J \& Li J 2013 A novel chemical uncoupler ameliorates obesity and related phenotypes in mice with diet-induced obesity by modulating energy expenditure and food intake. Diabetologia 56 2297-2307. (https://doi.org/10.1007/s00125-013-2987-9) 
Fujisaka S, Usui I, Bukhari A, Ikutani M, Oya T, Kanatani Y, Tsuneyama K, Nagai Y, Takatsu K, Urakaze M, et al. 2009 Regulatory mechanisms for adipose tissue M1 and M2 macrophages in dietinduced obese mice. Diabetes 58 2574-2582. (https://doi. org/10.2337/db08-1475)

Fujisaka S, Usui I, Ikutani M, Aminuddin A, Takikawa A, Tsuneyama K, Mahmood A, Goda N, Nagai Y, Takatsu K, et al. 2013 Adipose tissue hypoxia induces inflammatory M1 polarity of macrophages in an HIF-1 $\alpha$-dependent and HIF- $1 \alpha$-independent manner in obese mice. Diabetologia 56 1403-1412. (https://doi.org/10.1007/s00125-0132885-1)

Garofalo C, Sisci D \& Surmacz E 2004 Leptin interferes with the effects of the antiestrogen ICI 182,780 in MCF-7 breast cancer cells. Clinical Cancer Research 10 6466-6475. (https://doi.org/10.1158/1078-0432. CCR-04-0203)

Gonzalez RR, Cherfils S, Escobar M, Yoo JH, Carino C, Styer AK, Sullivan BT, Sakamoto H, Olawaiye A, Serikawa T, et al. 2006 Leptin signaling promotes the growth of mammary tumors and increases the expression of vascular endothelial growth factor (VEGF) and its receptor type two (VEGF-R2). Journal of Biological Chemistry 281 26320-26328. (https://doi.org/10.1074/jbc.M601991200)

Greten FR, Eckmann L, Greten TF, Park JM, Li Z-W, Egan LJ, Kagnoff MF \& Karin M 2004 IKKbeta links inflammation and tumorigenesis in a mouse model of colitis-associated cancer. Cell 118 285-296. (https:// doi.org/10.1016/j.cell.2004.07.013)

Gunter MJ, Hoover DR, Yu H, Wassertheil-Smoller S, Rohan TE, Manson JE, Li J, Ho GYF, Xue X, Anderson GL, et al. 2009 Insulin, insulin-like growth factor-I, and risk of breast cancer in postmenopausal women. Journal of the National Cancer Institute 101 48-60. (https://doi.org/10.1093/jnci/djn415)

Guo W, Key TJ \& Reeves GK 2018 Adiposity and breast cancer risk in postmenopausal women: results from the UK Biobank prospective cohort. International Journal of Cancer 143 1037-1046. (https://doi. org/10.1002/ijc.31394)

Halberg N, Khan T, Trujillo ME, Wernstedt-Asterholm I, Attie AD, Sherwani S, Wang ZV, Landskroner-Eiger S, Dineen S, Magalang UJ, et al. 2009 Hypoxia-inducible factor 1alpha induces fibrosis and insulin resistance in white adipose tissue. Molecular and Cellular Biology 29 4467-4483. (https://doi.org/10.1128/MCB.00192-09)

Han J, Hubbard BP, Lee J, Montagna C, Lee H-W, Sinclair DA \& Suh Y 2013 Analysis of 41 cancer cell lines reveals excessive allelic loss and novel mutations in the SIRT1 gene. Cell Cycle 12 263-270. (https:// doi.org/10.4161/cc.23056)

Harford KA, Reynolds CM, McGillicuddy FC \& Roche HM 2011 Fats, inflammation and insulin resistance: insights to the role of macrophage and T-cell accumulation in adipose tissue. Proceedings of the Nutrition Society 70 408-417. (https://doi.org/10.1017/S0029665111000565)

Harrington LS, Findlay GM, Gray A, Tolkacheva T, Wigfield S, Rebholz H, Barnett J, Leslie NR, Cheng S, Shepherd PR, et al. 2004 The TSC1-2 tumor suppressor controls insulin-PI3K signaling via regulation of IRS proteins. Journal of Cell Biology 166 213-223. (https://doi.org/10.1083/jcb.200403069)

Hay N \& Sonenberg N 2004 Upstream and downstream of mTOR. Genes and Development 18 1926-1945. (https://doi.org/10.1101/ gad.1212704)

Helczynska K, Larsson A-M, Holmquist Mengelbier L, Bridges E, Fredlund E, Borgquist S, Landberg G, Påhlman S \& Jirström K 2008 Hypoxia-inducible factor-2alpha correlates to distant recurrence and poor outcome in invasive breast cancer. Cancer Research $\mathbf{6 8}$ 9212-9220. (https://doi.org/10.1158/0008-5472.CAN-08-1135)

Holloway KR, Calhoun TN, Saxena M, Metoyer CF, Kandler EF, Rivera CA \& Pruitt K 2010 SIRT1 regulates Dishevelled proteins and promotes transient and constitutive Wnt signaling. PNAS 107 9216-9221. (https://doi.org/10.1073/pnas.0911325107)

Holloway KR, Barbieri A, Malyarchuk S, Saxena M, NedeljkovicKurepa A, Cameron Mehl M, Wang A, Gu X \& Pruitt K 2013 SIRT1 positively regulates breast cancer associated human aromatase (CYP19A1) expression. Molecular Endocrinology 27 480-490. (https:// doi.org/10.1210/me.2012-1347)

Hotamisligil GS 2010 Endoplasmic reticulum stress and the inflammatory basis of metabolic disease. Cell 140 900-917. (https:// doi.org/10.1016/j.cell.2010.02.034)

Hu N, Li Y, Zhao Y, Wang Q, You J, Zhang X \& Ye L 2011 A novel positive feedback loop involving FASN/p-ERK1/2/5-LOX/LTB4/FASN sustains high growth of breast cancer cells. Acta Pharmacologica Sinica 32 921-929. (https://doi.org/10.1038/aps.2011.40)

Huang J \& Manning BD 2009 A complex interplay between Akt, TSC2 and the two mTOR complexes. Biochemical Society Transactions $\mathbf{3 7}$ 217-222. (https://doi.org/10.1042/BST0370217)

Hui X, Zhang M, Gu P, Li K, Gao Y, Wu D, Wang Y \& Xu A 2017 Adipocyte SIRT1 controls systemic insulin sensitivity by modulating macrophages in adipose tissue. EMBO Reports 18 645-657. (https:// doi.org/10.15252/embr.201643184)

Huynh L, Kusnadi A, Park SH, Murata K, Park-Min K-H \& Ivashkiv LB 2016 Opposing regulation of the late phase TNF response by mTORC1-IL-10 signaling and hypoxia in human macrophages. Scientific Reports 6 31959. (https://doi.org/10.1038/srep31959)

Ichioka M, Suganami T, Tsuda N, Shirakawa I, Hirata Y, Satoh-Asahara N, Shimoda Y, Tanaka M, Kim-Saijo M, Miyamoto Y, et al. 2011 Increased expression of macrophage-inducible C-type lectin in adipose tissue of obese mice and humans. Diabetes 60 819-826. (https://doi.org/10.2337/db10-0864)

Inoki K, Li Y, Zhu T, Wu J \& Guan K-L 2002 TSC2 is phosphorylated and inhibited by Akt and suppresses mTOR signalling. Nature Cell Biology 4 648-657. (https://doi.org/10.1038/ncb839)

Ishikawa M, Kitayama J \& Nagawa H 2004 Enhanced expression of leptin and leptin receptor (OB-R) in human breast cancer. Clinical Cancer Research 10 4325-4331. (https://doi.org/10.1158/1078-0432. CCR-03-0749)

Iwase T, Sangai T, Nagashima T, Sakakibara M, Sakakibara J, Hayama S, Ishigami E, Masuda T \& Miyazaki M 2016 Impact of body fat distribution on neoadjuvant chemotherapy outcomes in advanced breast cancer patients. Cancer Medicine 5 41-48. (https://doi. org/10.1002/cam4.571)

Jackson JG, Zhang X, Yoneda T \& Yee D 2001 Regulation of breast cancer cell motility by insulin receptor substrate-2 (IRS-2) in metastatic variants of human breast cancer cell lines. Oncogene 20 7318-7325. (https://doi.org/10.1038/sj.onc.1204920)

Janiszewski PM, Saunders TJ \& Ross R 2010 Breast volume is an independent predictor of visceral and ectopic fat in premenopausal women. Obesity 18 1183-1187. (https://doi.org/10.1038/ oby.2009.336)

Jardé T, Caldefie-Chézet F, Damez M, Mishellany F, Penault-Llorca F, Guillot J \& Vasson MP 2008 Leptin and leptin receptor involvement in cancer development: a study on human primary breast carcinoma. Oncology Reports 19 905-911. (https://doi.org/10.3892/ or.19.4.905)

Jiang WG, Sampson J, Martin TA, Lee-Jones L, Watkins G, DouglasJones A, Mokbel K \& Mansel RE 2005 Tuberin and hamartin are aberrantly expressed and linked to clinical outcome in human breast cancer: the role of promoter methylation of TSC genes. European Journal of Cancer 41 1628-1636. (https://doi.org/10.1016/j. ejca.2005.03.023)

Jiang C, Qu A, Matsubara T, Chanturiya T, Jou W, Gavrilova O, Shah YM \& Gonzalez FJ 2011 Disruption of hypoxia-inducible factor 1 in adipocytes improves insulin sensitivity and decreases adiposity in high-fat diet-fed mice. Diabetes 60 2484-2495. (https://doi. org/10.2337/db11-0174)

Jiang H, Westerterp M, Wang C, Zhu Y \& Ai D 2014 Macrophage mTORC1 disruption reduces inflammation and insulin resistance in obese mice. Diabetologia 57 2393-2404. (https://doi.org/10.1007/ s00125-014-3350-5) 
Juhas U, Ryba-Stanisławowska M, Szargiej P \& Myśliwska J 2015 Different pathways of macrophage activation and polarization. Postepy Higieny I Medycyny Doswiadczalnej 69 496-502. (https://doi. org/10.5604/17322693.1150133)

Kanda H, Tateya S, Tamori Y, Kotani K, Hiasa K, Kitazawa R, Kitazawa S, Miyachi H, Maeda S, Egashira K, et al. 2006 MCP-1 contributes to macrophage infiltration into adipose tissue, insulin resistance, and hepatic steatosis in obesity. Journal of Clinical Investigation 116 1494-1505. (https://doi.org/10.1172/JCI26498)

Karin M \& Greten FR 2005 NF-kappaB: linking inflammation and immunity to cancer development and progression. Nature Reviews Immunology 5 749-759. (https://doi.org/10.1038/nri1703)

Kern PA, Ranganathan S, Li C, Wood L \& Ranganathan G 2001 Adipose tissue tumor necrosis factor and interleukin- 6 expression in human obesity and insulin resistance. American Journal of Physiology: Endocrinology and Metabolism 280 E745-E751. (https://doi. org/10.1152/ajpendo.2001.280.5.E745)

Keuper M, Blüher M, Schön MR, Möller P, Dzyakanchuk A, Amrein K, Debatin K-M, Wabitsch M \& Fischer-Posovszky P 2011 An inflammatory micro-environment promotes human adipocyte apoptosis. Molecular and Cellular Endocrinology 339 105-113. (https:// doi.org/10.1016/j.mce.2011.04.004)

Khabaz MN, Abdelrahman A, Butt N, Damnhory L, Elshal M, Aldahlawi AM, Ashoor S, Al-Maghrabi B, Dobson P, Brown B, et al. 2017 Immunohistochemical staining of leptin is associated with grade, stage, lymph node involvement, recurrence, and hormone receptor phenotypes in breast cancer. BMC Women's Health 17105. (https://doi.org/10.1186/s12905-017-0459-y)

Kim SY, Jeong E, Joung SM \& Lee JY 2012 PI3K/Akt contributes to increased expression of Toll-like receptor 4 in macrophages exposed to hypoxic stress. Biochemical and Biophysical Research Communications 419 466-471. (https://doi.org/10.1016/j.bbrc.2012.02.015)

Kim J, Lee YH, Park JHY \& Sung M-K 2015 Estrogen deprivation and excess energy supply accelerate 7,12-dimethylbenz(a)anthraceneinduced mammary tumor growth in $\mathrm{C} 3 \mathrm{H} / \mathrm{HeN}$ mice. Nutrition Research and Practice 9 628-636. (https://doi.org/10.4162/ nrp.2015.9.6.628)

Kosteli A, Sugaru E, Haemmerle G, Martin JF, Lei J, Zechner R \& Ferrante AW 2010 Weight loss and lipolysis promote a dynamic immune response in murine adipose tissue. Journal of Clinical Investigation 120 3466-3479. (https://doi.org/10.1172/JCI42845)

Krahling S, Callahan MK, Williamson P \& Schlegel RA 1999 Exposure of phosphatidylserine is a general feature in the phagocytosis of apoptotic lymphocytes by macrophages. Cell Death and Differentiation 6 183-189. (https://doi.org/10.1038/sj.cdd.4400473)

Krausgruber T, Blazek K, Smallie T, Alzabin S, Lockstone H, Sahgal N, Hussell T, Feldmann M \& Udalova IA 2011 IRF5 promotes inflammatory macrophage polarization and TH1-TH17 responses. Nature Immunology 12 231-238. (https://doi.org/10.1038/ni.1990)

Laplante M \& Sabatini DM 2009 An emerging role of mTOR in lipid biosynthesis. Current Biology 19 R1046-R1052. (https://doi. org/10.1016/j.cub.2009.09.058)

Laplante M \& Sabatini DM 2012 mTOR signaling in growth control and disease. Cell 149 274-293. (https://doi.org/10.1016/j. cell.2012.03.017)

Lawlor MA \& Alessi DR 2001 PKB/Akt: a key mediator of cell proliferation, survival and insulin responses? Journal of Cell Science $1142903-2910$.

Lee D-F \& Hung M-C 2007 All roads lead to mTOR: integrating inflammation and tumor angiogenesis. Cell Cycle 6 3011-3014. (https://doi.org/10.4161/cc.6.24.5085)

Lee CH \& Lam KS 2018 Obesity-induced insulin resistance and macrophage infiltration of the adipose tissue: a vicious cycle. Journal of Diabetes Investigation 10 29-31. (https://doi.org/10.1111/jdi.12918)

Lee AV, Jackson JG, Gooch JL, Hilsenbeck SG, Coronado-Heinsohn E, Osborne CK \& Yee D 1999 Enhancement of insulin-like growth factor signaling in human breast cancer: estrogen regulation of insulin receptor substrate-1 expression in vitro and in vivo. Molecular Endocrinology 13 787-796. (https://doi.org/10.1210/mend.13.5.0274)

Lee D-F, Kuo H-P, Chen C-T, Hsu J-M, Chou C-K, Wei Y, Sun H-L, Li L-Y, Ping B, Huang W-C, et al. 2007 IKK beta suppression of TSC1 links inflammation and tumor angiogenesis via the mTOR pathway. Cell 130 440-455. (https://doi.org/10.1016/j.cell.2007.05.058)

Lee D-F, Kuo H-P, Chen C-T, Wei Y, Chou C-K, Hung J-Y, Yen C-J \& Hung M-C 2008 IKKbeta suppression of TSC1 function links the mTOR pathway with insulin resistance. International Journal of Molecular Medicine 22 633-638. (https://doi.org/10.3892/ ijmm_00000065)

Lee KY, Gesta S, Boucher J, Wang XL \& Kahn CR 2011 The differential role of Hif1 $\beta /$ Arnt and the hypoxic response in adipose function, fibrosis, and inflammation. Cell Metabolism 14 491-503. (https://doi. org/10.1016/j.cmet.2011.08.006)

Lee YS, Kim J, Osborne O, Oh DY, Sasik R, Schenk S, Chen A, Chung H, Murphy A, Watkins SM, et al. 2014 Increased adipocyte O2 consumption triggers HIF- $1 \alpha$, causing inflammation and insulin resistance in obesity. Cell 157 1339-1352. (https://doi.org/10.1016/j. cell.2014.05.012)

Li J \& Han X 2018 Adipocytokines and breast cancer. Current Problems in Cancer 42 208-214. (https://doi.org/10.1016/j. currproblcancer.2018.01.004)

Li CI, Malone KE \& Daling JR 2006 Interactions between body mass index and hormone therapy and postmenopausal breast cancer risk (United States). Cancer Causes and Control 17 695-703. (https://doi. org/10.1007/s10552-005-0001-7)

Li P, Oh DY, Bandyopadhyay G, Lagakos WS, Talukdar S, Osborn O, Johnson A, Chung H, Maris M, Ofrecio JM, et al. 2015 LTB4 promotes insulin resistance in obese mice by acting on macrophages, hepatocytes and myocytes. Nature Medicine 21 239-247. (https://doi. org/10.1038/nm.3800)

Liang X, Wang S, Wang X, Zhang L, Zhao H \& Zhang L 2018 Leptin promotes the growth of breast cancer by upregulating the Wnt $/ \beta$ catenin pathway. Experimental and Therapeutic Medicine 16 767-771. (https://doi.org/10.3892/etm.2018.6212)

Lim EJ, Hong DY, Park JH, Joung YH, Darvin P, Kim SY, Na YM, Hwang TS, Ye S-K, Moon E-S, et al. 2012 Methylsulfonylmethane suppresses breast cancer growth by down-regulating STAT3 and STAT5b pathways. PLOS ONE 7 e33361. (https://doi.org/10.1371/ journal.pone.0033361)

Liu G, Schwartz JA \& Brooks SC 1999 p53 down-regulates ER-responsive genes by interfering with the binding of ER to ERE. Biochemical and Biophysical Research Communications 264 359-364. (https://doi. org/10.1006/bbrc.1999.1525)

Liu M, Bai J, He S, Villarreal R, Hu D, Zhang C, Yang X, Liang H, Slaga TJ, Yu Y, et al. 2014 Grb10 promotes lipolysis and thermogenesis by phosphorylation-dependent feedback inhibition of mTORC1. Cell Metabolism 19 967-980. (https://doi.org/10.1016/j. cmet.2014.03.018)

Liu Z, Gan L, Liu G, Chen Y, Wu T, Feng F \& Sun C 2016 Sirt1 decreased adipose inflammation by interacting with Akt2 and inhibiting mTOR/S6K1 pathway in mice. Journal of Lipid Research $\mathbf{5 7}$ 1373-1381. (https://doi.org/10.1194/jlr.M063537)

Liu Y, Xu D, Yin C, Wang S, Wang M \& Xiao Y 2018 IL-10/STAT3 is reduced in childhood obesity with hypertriglyceridemia and is related to triglyceride level in diet-induced obese rats. BMC Endocrine Disorders 18 39. (https://doi.org/10.1186/s12902-018-0265-z)

Loewith R, Jacinto E, Wullschleger S, Lorberg A, Crespo JL, Bonenfant D, Oppliger W, Jenoe P \& Hall MN 2002 Two TOR complexes, only one of which is rapamycin sensitive, have distinct roles in cell growth control. Molecular Cell 10 457-468. (https://doi.org/10.1016/S10972765(02)00636-6)

Lukanova A, Lundin E, Zeleniuch-Jacquotte A, Muti P, Mure A, Rinaldi S, Dossus L, Micheli A, Arslan A, Lenner P, et al. 2004 Body mass index, 
circulating levels of sex-steroid hormones, IGF-I and IGF-binding protein-3: a cross-sectional study in healthy women. European Journal of Endocrinology 150 161-171. (https://doi.org/10.1530/ eje.0.1500161)

Lumeng CN \& Saltiel AR 2011 Inflammatory links between obesity and metabolic disease. Journal of Clinical Investigation 121 2111-2117. (https://doi.org/10.1172/JCI57132)

Lumeng CN, Bodzin JL \& Saltiel AR 2007a Obesity induces a phenotypic switch in adipose tissue macrophage polarization. Journal of Clinical Investigation 117 175-184. (https://doi.org/10.1172/JCI29881)

Lumeng CN, Deyoung SM \& Saltiel AR 2007b Macrophages block insulin action in adipocytes by altering expression of signaling and glucose transport proteins. American Journal of Physiology: Endocrinology and Metabolism 292 E166-E174. (https://doi. org/10.1152/ajpendo.00284.2006)

Lumeng CN, DelProposto JB, Westcott DJ \& Saltiel AR 2008 Phenotypic switching of adipose tissue macrophages with obesity is generated by spatiotemporal differences in macrophage subtypes. Diabetes $\mathbf{5 7}$ 3239-3246. (https://doi.org/10.2337/db08-0872)

Ma L, Chen Z, Erdjument-Bromage H, Tempst P \& Pandolfi PP 2005 Phosphorylation and functional inactivation of TSC2 by Erk implications for tuberous sclerosis and cancer pathogenesis. Cell 121 179-193. (https://doi.org/10.1016/j.cell.2005.02.031)

Maffei M, Halaas J, Ravussin E, Pratley RE, Lee GH, Zhang Y, Fei H, Kim S, Lallone R \& Ranganathan S 1995 Leptin levels in human and rodent: measurement of plasma leptin and ob RNA in obese and weight-reduced subjects. Nature Medicine 1 1155-1161. (https://doi. org/10.1038/nm1195-1155)

Malaguarnera R, Nicolosi ML, Sacco A, Morcavallo A, Vella V, Voci C, Spatuzza M, Xu S-Q, Iozzo RV, Vigneri R, et al. 2015 Novel cross talk between IGF-IR and DDR1 regulates IGF-IR trafficking, signaling and biological responses. Oncotarget 6 16084-16105. (https://doi. org/10.18632/oncotarget.3177)

Manning BD, Tee AR, Logsdon MN, Blenis J \& Cantley LC 2002 Identification of the tuberous sclerosis complex-2 tumor suppressor gene product tuberin as a target of the phosphoinositide 3-kinase/ akt pathway. Molecular Cell 10 151-162. (https://doi.org/10.1016/ S1097-2765(02)00568-3)

Marttunen MB, Andersson S, Hietanen P, Karonen SL, Koistinen HA, Koivisto VA, Tiitinen A \& Ylikorkala O 2000 Antiestrogenic tamoxifen and toremifene increase serum leptin levels in postmenopausal breast cancer patients. Maturitas 35 175-179. (https://doi.org/10.1016/S0378-5122(00)00121-3)

Masarwi M, Shamir R, Phillip M \& Gat-Yablonski G 2018 Leptin stimulates aromatase in the growth plate: limiting catch-up growth efficiency. Journal of Endocrinology 237 229-242. (https://doi. org/10.1530/JOE-18-0028)

Matà R, Palladino C, Nicolosi ML, Lo Presti AR, Malaguarnera R, Ragusa M, Sciortino D, Morrione A, Maggiolini M, Vella V, et al. 2016 IGF-I induces upregulation of DDR1 collagen receptor in breast cancer cells by suppressing MIR-199a-5p through the PI3K/AKT pathway. Oncotarget 7 7683-7700. (https://doi.org/10.18632/ oncotarget.6524)

Mawson A, Lai A, Carroll JS, Sergio CM, Mitchell CJ \& Sarcevic B 2005 Estrogen and insulin/IGF-1 cooperatively stimulate cell cycle progression in MCF-7 breast cancer cells through differential regulation of c-Myc and cyclin D1. Molecular and Cellular Endocrinology 229 161-173. (https://doi.org/10.1016/j. mce.2004.08.002)

McDonnell DP, Chang C-Y \& Nelson ER 2014 The estrogen receptor as a mediator of the pathological actions of cholesterol in breast cancer. Climacteric 17 (Supplement 2) 60-65. (https://doi.org/10.3109/13697 137.2014.966949)

McTiernan A, Rajan KB, Tworoger SS, Irwin M, Bernstein L, Baumgartner R, Gilliland F, Stanczyk FZ, Yasui Y \& Ballard-Barbash R 2003 Adiposity and sex hormones in postmenopausal breast cancer survivors. Journal of Clinical Oncology 21 1961-1966. (https://doi. org/10.1200/JCO.2003.07.057)

Mehta MS, Vazquez A, Kulkarni DA, Kerrigan JE, Atwal G, Metsugi S, Toppmeyer DL, Levine AJ \& Hirshfield KM 2011 Polymorphic variants in TSC1 and TSC2 and their association with breast cancer phenotypes. Breast Cancer Research and Treatment 125 861-868. (https://doi.org/10.1007/s10549-010-1062-1)

Meijer AJ \& Codogno P 2004 Regulation and role of autophagy in mammalian cells. International Journal of Biochemistry and Cell Biology 36 2445-2462. (https://doi.org/10.1016/j.biocel.2004.02.002)

Menendez JA \& Lupu R 2007 Fatty acid synthase and the lipogenic phenotype in cancer pathogenesis. Nature Reviews Cancer 7 763-777. (https://doi.org/10.1038/nrc2222)

Mihaylova MM \& Shaw RJ 2011 The AMPK signalling pathway coordinates cell growth, autophagy and metabolism. Nature Cell Biology 13 1016-1023. (https://doi.org/10.1038/ncb2329)

Milazzo G, Giorgino F, Damante G, Sung C, Stampfer MR, Vigneri R, Goldfine ID \& Belfiore A 1992 Insulin receptor expression and function in human breast cancer cell lines. Cancer Research 52 3924-3930.

Miller TW, Balko JM \& Arteaga CL 2011 Phosphatidylinositol 3-kinase and antiestrogen resistance in breast cancer. Journal of Clinical Oncology 29 4452-4461. (https://doi.org/10.1200/JCO.2010.34.4879)

Minakshi R, Rahman S, Jan AT, Archana A \& Kim J 2017 Implications of aging and the endoplasmic reticulum unfolded protein response on the molecular modality of breast cancer. Experimental and Molecular Medicine 49 e389. (https://doi.org/10.1038/emm.2017.215)

Molina L, Figueroa CD, Bhoola KD \& Ehrenfeld P 2017 GPER-1/GPR30 a novel estrogen receptor sited in the cell membrane: therapeutic coupling to breast cancer. Expert Opinion on Therapeutic Targets 21 755-766. (https://doi.org/10.1080/14728222.2017.1350264)

Moreno-Navarrete JM, Moreno M, Vidal M, Ortega F, Ricart W \& Fernández-Real JM 2015 DBC1 is involved in adipocyte inflammation and is a possible marker of human adipose tissue senescence. Obesity 23 519-522. (https://doi.org/10.1002/oby.20999)

Morris PG, Hudis CA, Giri D, Morrow M, Falcone DJ, Zhou XK, Du B, Brogi E, Crawford CB, Kopelovich L, et al. 2011 Inflammation and increased aromatase expression occur in the breast tissue of obese women with breast cancer. Cancer Prevention Research 4 1021-1029. (https://doi.org/10.1158/1940-6207.CAPR-11-0110)

Murano I, Barbatelli G, Parisani V, Latini C, Muzzonigro G, Castellucci M \& Cinti S 2008 Dead adipocytes, detected as crownlike structures, are prevalent in visceral fat depots of genetically obese mice. Journal of Lipid Research 49 1562-1568. (https://doi. org/10.1194/jlr.M800019-JLR200)

Murdoch C, Giannoudis A \& Lewis CE 2004 Mechanisms regulating the recruitment of macrophages into hypoxic areas of tumors and other ischemic tissues. Blood 104 2224-2234. (https://doi.org/10.1182/ blood-2004-03-1109)

Nam SY, Lee EJ, Kim KR, Cha BS, Song YD, Lim SK, Lee HC \& Huh KB 1997 Effect of obesity on total and free insulin-like growth factor (IGF)-1, and their relationship to IGF-binding protein (BP)-1, IGFBP2, IGFBP-3, insulin, and growth hormone. International Journal of Obesity and Related Metabolic Disorders 21 355-359. (https://doi. org/10.1038/sj.ijo.0800412)

Nazio F, Strappazzon F, Antonioli M, Bielli P, Cianfanelli V, Bordi M, Gretzmeier C, Dengjel J, Piacentini M, Fimia GM, et al. 2013 mTOR inhibits autophagy by controlling ULK1 ubiquitylation, selfassociation and function through AMBRA1 and TRAF6. Nature Cell Biology 15 406-416. (https://doi.org/10.1038/ncb2708)

Newman G \& Gonzalez-Perez RR 2014 Leptin-cytokine crosstalk in breast cancer. Molecular and Cellular Endocrinology 382 570-582. (https://doi.org/10.1016/j.mce.2013.03.025)

Ng M, Fleming T, Robinson M, Thomson B, Graetz N, Margono C, Mullany EC, Biryukov S, Abbafati C, Abera SF, et al. 2014 Global, regional, and national prevalence of overweight and obesity in 
children and adults during 1980-2013: a systematic analysis for the Global Burden of Disease Study 2013. Lancet 384 766-781. (https:// doi.org/10.1016/S0140-6736(14)60460-8)

Nin V, Escande C, Chini CC, Giri S, Camacho-Pereira J, Matalonga J, Lou Z \& Chini EN 2012 Role of deleted in breast cancer 1 (DBC1) protein in SIRT1 deacetylase activation induced by protein kinase A and AMP-activated protein kinase. Journal of Biological Chemistry $\mathbf{2 8 7}$ 23489-23501. (https://doi.org/10.1074/jbc.M112.365874)

Novosyadlyy R, Lann DE, Vijayakumar A, Rowzee A, Lazzarino DA, Fierz Y, Carboni JM, Gottardis MM, Pennisi PA, Molinolo AA, et al. 2010 Insulin-mediated acceleration of breast cancer development and progression in a nonobese model of type 2 diabetes. Cancer Research 70 741-751. (https://doi.org/10.1158/0008-5472.CAN-092141)

Obeid E, Nanda R, Fu Y-X \& Olopade OI 2013 The role of tumorassociated macrophages in breast cancer progression (review). International Journal of Oncology 43 5-12. (https://doi.org/10.3892/ ijo.2013.1938)

Obeid J-P, Stoyanova R, Kwon D, Patel M, Padgett K, Slingerland J, Takita C, Alperin N, Yepes M \& Zeidan YH 2017 Multiparametric evaluation of preoperative MRI in early stage breast cancer: prognostic impact of peri-tumoral fat. Clinical and Translational Oncology 19 211-218. (https://doi.org/10.1007/s12094-016-1526-9)

O'Donnell EF, Koch DC, Bisson WH, Jang HS \& Kolluri SK 2014 The aryl hydrocarbon receptor mediates raloxifene-induced apoptosis in estrogen receptor-negative hepatoma and breast cancer cells. Cell Death and Disease 5 e1038. (https://doi.org/10.1038/cddis.2013.549)

Olefsky JM \& Glass CK 2010 Macrophages, inflammation, and insulin resistance. Annual Review of Physiology 72 219-246. (https://doi. org/10.1146/annurev-physiol-021909-135846)

O'Rourke RW, White AE, Metcalf MD, Olivas AS, Mitra P, Larison WG, Cheang EC, Varlamov O, Corless CL, Roberts CT, et al. 2011 Hypoxia-induced inflammatory cytokine secretion in human adipose tissue stromovascular cells. Diabetologia 54 1480-1490. (https://doi. org/10.1007/s00125-011-2103-y)

Ozcan U, Cao Q, Yilmaz E, Lee A-H, Iwakoshi NN, Ozdelen E, Tuncman G, Görgün C, Glimcher LH \& Hotamisligil GS 2004 Endoplasmic reticulum stress links obesity, insulin action, and type 2 diabetes. Science 306 457-461. (https://doi.org/10.1126/ science.1103160)

Ozcan U, Ozcan L, Yilmaz E, Düvel K, Sahin M, Manning BD \& Hotamisligil GS 2008 Loss of the tuberous sclerosis complex tumor suppressors triggers the unfolded protein response to regulate insulin signaling and apoptosis. Molecular Cell 29 541-551. (https://doi. org/10.1016/j.molcel.2007.12.023)

Pal D, Dasgupta S, Kundu R, Maitra S, Das G, Mukhopadhyay S, Ray S, Majumdar SS \& Bhattacharya S 2012 Fetuin-A acts as an endogenous ligand of TLR4 to promote lipid-induced insulin resistance. Nature Medicine 18 1279-1285. (https://doi.org/10.1038/nm.2851)

Papanikolaou V, Stefanou N, Dubos S, Papathanasiou I, Palianopoulou M, Valiakou V \& Tsezou A 2015 Synergy of leptin/ STAT3 with HER2 receptor induces tamoxifen resistance in breast cancer cells through regulation of apoptosis-related genes. Cellular Oncology 38 155-164. (https://doi.org/10.1007/s13402-014-0213-5)

Park SW, Zhou Y, Lee J, Lu A, Sun C, Chung J, Ueki K \& Ozcan U 2010 The regulatory subunits of PI3K, p85alpha and p85beta, interact with XBP-1 and increase its nuclear translocation. Nature Medicine 16 429-437. (https://doi.org/10.1038/nm.2099)

Park SH, Riley P \& Frisch SM 2013 Regulation of anoikis by deleted in breast cancer-1 (DBC1) through NF-кB. Apoptosis 18 949-962. (https://doi.org/10.1007/s10495-013-0847-1)

Park EY, Woo Y, Kim SJ, Kim DH, Lee EK, De U, Kim KS, Lee J, Jung JH, Ha K-T, et al. 2016 Anticancer effects of a new SIRT inhibitor, MHY2256, against human breast cancer MCF-7 cells via regulation of MDM2-p53 binding. International Journal of Biological Sciences 12 1555-1567. (https://doi.org/10.7150/ijbs.13833)
Pasarica M, Sereda OR, Redman LM, Albarado DC, Hymel DT, Roan LE, Rood JC, Burk DH \& Smith SR 2009 Reduced adipose tissue oxygenation in human obesity: evidence for rarefaction, macrophage chemotaxis, and inflammation without an angiogenic response. Diabetes 58 718-725. (https://doi.org/10.2337/db08-1098)

Paschoal VA, Amano MT, Belchior T, Magdalon J, Chimin P, Andrade ML, Ortiz-Silva M, Castro É, Yamashita AS, Rosa Neto JC, et al. 2017 mTORC1 inhibition with rapamycin exacerbates adipose tissue inflammation in obese mice and dissociates macrophage phenotype from function. Immunobiology 222 261-271. (https://doi. org/10.1016/j.imbio.2016.09.014)

Paschoal VA, Belchior T, Amano MT, Burgos-Silva M, Peixoto AS, Magdalon J, Vieira TS, Andrade ML, Moreno MF, Chimin P, et al. 2018 Constitutive activation of the nutrient sensor mTORC1 in myeloid cells induced by Tsc1 deletion protects mice from dietinduced obesity. Molecular Nutrition and Food Research 62 e1800283. (https://doi.org/10.1002/mnfr.201800283)

Peng J, Wu Y, Deng Z, Zhou Y, Song T, Yang Y, Zhang X, Xu T, Xia M, Cai A, et al. 2017 MiR-377 promotes white adipose tissue inflammation and decreases insulin sensitivity in obesity via suppression of sirtuin-1 (SIRT1). Oncotarget 8 70550-70563. (https:// doi.org/10.18632/oncotarget.19742)

Pfeiler G, Königsberg R, Hadji P, Fitzal F, Maroske M, Dressel-Ban G, Zellinger J, Exner R, Seifert M, Singer C, et al. 2013 Impact of body mass index on estradiol depletion by aromatase inhibitors in postmenopausal women with early breast cancer. British Journal of Cancer 109 1522-1527. (https://doi.org/10.1038/bjc.2013.499)

Pfeilschifter J, Köditz R, Pfohl M \& Schatz H 2002 Changes in proinflammatory cytokine activity after menopause. Endocrine Reviews 23 90-119. (https://doi.org/10.1210/edrv.23.1.0456)

Potter CJ, Pedraza LG \& Xu T 2002 Akt regulates growth by directly phosphorylating Tsc2. Nature Cell Biology 4 658-665. (https://doi. org/10.1038/ncb840)

Qiang L, Kon N, Zhao W, Jiang L, Knight CM, Welch C, Pajvani U, Gu W \& Accili D 2015 Hepatic SirT1-dependent gain of function of stearoyl-CoA desaturase-1 conveys dysmetabolic and tumor progression functions. Cell Reports 11 1797-1808. (https://doi. org/10.1016/j.celrep.2015.05.025)

Rausch LK, Netzer NC, Hoegel J \& Pramsohler S 2017 The linkage between breast cancer, hypoxia, and adipose tissue. Frontiers in Oncology 7 211. (https://doi.org/10.3389/fonc.2017.00211)

Renehan AG, Frystyk J \& Flyvbjerg A 2006 Obesity and cancer risk: the role of the insulin-IGF axis. Trends in Endocrinology and Metabolism 17 328-336. (https://doi.org/10.1016/j.tem.2006.08.006)

Rios Garcia M, Steinbauer B, Srivastava K, Singhal M, Mattijssen F, Maida A, Christian S, Hess-Stumpp H, Augustin HG, MüllerDecker K, et al. 2017 Acetyl-CoA carboxylase 1-dependent protein acetylation controls breast cancer metastasis and recurrence. Cell Metabolism 26 842.e5-855.e5. (https://doi.org/10.1016/j. cmet.2017.09.018)

Rodgers JT, Lerin C, Haas W, Gygi SP, Spiegelman BM \& Puigserver P 2005 Nutrient control of glucose homeostasis through a complex of PGC-1alpha and SIRT1. Nature 434 113-118. (https://doi. org/10.1038/nature03354)

Ron D \& Harding HP 2012 Protein-folding homeostasis in the endoplasmic reticulum and nutritional regulation. Cold Spring Harbor Perspectives in Biology 4. (https://doi.org/10.1101/cshperspect. a013177)

Rose DP \& Vona-Davis L 2014 Biochemical and molecular mechanisms for the association between obesity, chronic inflammation, and breast cancer. BioFactors 40 1-12. (https://doi.org/10.1002/biof.1109)

Russo L \& Lumeng CN 2018 Properties and functions of adipose tissue macrophages in obesity. Immunology 155 407-417. (https://doi. org/10.1111/imm.13002)

Rydén L, Heibert Arnlind M, Vitols S, Höistad M \& Ahlgren J 2016 Aromatase inhibitors alone or sequentially combined with tamoxifen 
in postmenopausal early breast cancer compared with tamoxifen or placebo - meta-analyses on efficacy and adverse events based on randomized clinical trials. Breast 26 106-114. (https://doi. org/10.1016/j.breast.2016.01.006)

Saito R, Miki Y, Hata S, Ishida T, Suzuki T, Ohuchi N \& Sasano H 2017 Aryl hydrocarbon receptor induced intratumoral aromatase in breast cancer. Breast Cancer Research and Treatment 161 399-407. (https:// doi.org/10.1007/s10549-016-4063-x)

Salisbury TB, Morris GZ, Tomblin JK, Chaudhry AR, Cook CR \& Santanam N 2013 Aryl hydrocarbon receptor ligands inhibit igf-ii and adipokine stimulated breast cancer cell proliferation. ISRN Endocrinology 2013 104850. (https://doi.org/10.1155/2013/104850)

Sano S, Izumi Y, Yamaguchi T, Yamazaki T, Tanaka M, Shiota M, OsadaOka M, Nakamura Y, Wei M, Wanibuchi H, et al. 2014 Lipid synthesis is promoted by hypoxic adipocyte-derived exosomes in 3T3-L1 cells. Biochemical and Biophysical Research Communications 445 327-333. (https://doi.org/10.1016/j.bbrc.2014.01.183)

Sasser AK, Sullivan NJ, Studebaker AW, Hendey LF, Axel AE \& Hall BM 2007 Interleukin-6 is a potent growth factor for ER-alpha-positive human breast cancer. FASEB Journal 21 3763-3770. (https://doi. org/10.1096/fj.07-8832com)

Schelbert KB 2009 Comorbidities of obesity. Primary Care 36 271-285. (https://doi.org/10.1016/j.pop.2009.01.009)

Schmidt S, Monk JM, Robinson LE \& Mourtzakis M 2015 The integrative role of leptin, oestrogen and the insulin family in obesity-associated breast cancer: potential effects of exercise. Obesity Reviews $\mathbf{1 6}$ 473-487. (https://doi.org/10.1111/obr.12281)

Shan T, Zhang P, Jiang Q, Xiong Y, Wang Y \& Kuang S 2016 Adipocytespecific deletion of mTOR inhibits adipose tissue development and causes insulin resistance in mice. Diabetologia 59 1995-2004. (https://doi.org/10.1007/s00125-016-4006-4)

Shapiro H, Pecht T, Shaco-Levy R, Harman-Boehm I, Kirshtein B, Kuperman Y, Chen A, Blüher M, Shai I \& Rudich A 2013 Adipose tissue foam cells are present in human obesity. Journal of Clinical Endocrinology and Metabolism 98 1173-1181. (https://doi. org/10.1210/jc.2012-2745)

Sharma VR, Gupta GK, Sharma AK, Batra N, Sharma DK, Joshi A \& Sharma AK 2017 PI3K/Akt/mTOR intracellular pathway and breast cancer: factors, mechanism and regulation. Current Pharmaceutical Design 23 1633-1638. (https://doi.org/10.2174/138161282366616111 6125218)

Shi H, Kokoeva MV, Inouye K, Tzameli I, Yin H \& Flier JS 2006 TLR4 links innate immunity and fatty acid-induced insulin resistance. Journal of Clinical Investigation 116 3015-3025. (https://doi. org/10.1172/JCI28898)

Shi L, Dong B, Li Z, Lu Y, Ouyang T, Li J, Wang T, Fan Z, Fan T, Lin B, et al. 2009 Expression of ER-\{alpha\}36, a novel variant of estrogen receptor \{alpha\}, and resistance to tamoxifen treatment in breast cancer. Journal of Clinical Oncology 27 3423-3429. (https://doi. org/10.1200/JCO.2008.17.2254)

Siddle K 2011 Signalling by insulin and IGF receptors: supporting acts and new players. Journal of Molecular Endocrinology 47 R1-R10. (https://doi.org/10.1530/JME-11-0022)

Simone V, D'Avenia M, Argentiero A, Felici C, Rizzo FM, De Pergola G \& Silvestris F 2016 Obesity and breast cancer: molecular interconnections and potential clinical applications. Oncologist 21 404-417. (https://doi.org/10.1634/theoncologist.2015-0351)

Snodgrass RG, Boß M, Zezina E, Weigert A, Dehne N, Fleming I, Brüne B \& Namgaladze D 2016 Hypoxia potentiates palmitate-induced proinflammatory activation of primary human macrophages. Journal of Biological Chemistry 291 413-424. (https://doi.org/10.1074/jbc. M115.686709)

Soliman GA 2011 The integral role of mTOR in lipid metabolism. Cell Cycle 10 861-862. (https://doi.org/10.4161/cc.10.6.14930)

Song S, Tan J, Miao Y, Li M \& Zhang Q 2017 Crosstalk of autophagy and apoptosis: involvement of the dual role of autophagy under ER stress. Journal of Cellular Physiology 232 2977-2984. (https://doi. org/10.1002/jcp.25785)

Spalding KL, Arner E, Westermark PO, Bernard S, Buchholz BA, Bergmann O, Blomqvist L, Hoffstedt J, Näslund E, Britton T, et al. 2008 Dynamics of fat cell turnover in humans. Nature 453 783-787. (https://doi.org/10.1038/nature06902)

Spencer M, Yao-Borengasser A, Unal R, Rasouli N, Gurley CM, Zhu B, Peterson CA \& Kern PA 2010 Adipose tissue macrophages in insulinresistant subjects are associated with collagen VI and fibrosis and demonstrate alternative activation. American Journal of Physiology: Endocrinology and Metabolism 299 E1016-E1027. (https://doi. org/10.1152/ajpendo.00329.2010)

Subbaramaiah K, Morris PG, Zhou XK, Morrow M, Du B, Giri D, Kopelovich L, Hudis CA \& Dannenberg AJ 2012 Increased levels of COX-2 and prostaglandin E2 contribute to elevated aromatase expression in inflamed breast tissue of obese women. Cancer Discovery 2 356-365. (https://doi.org/10.1158/2159-8290.CD-11-0241)

Suganami T \& Ogawa Y 2010 Adipose tissue macrophages: their role in adipose tissue remodeling. Journal of Leukocyte Biology 88 33-39. (https://doi.org/10.1189/jlb.0210072)

Suganami T, Nishida J \& Ogawa Y 2005 A paracrine loop between adipocytes and macrophages aggravates inflammatory changes: role of free fatty acids and tumor necrosis factor alpha. Arteriosclerosis, Thrombosis, and Vascular Biology 25 2062-2068. (https://doi. org/10.1161/01.ATV.0000183883.72263.13)

Suganami T, Tanimoto-Koyama K, Nishida J, Itoh M, Yuan X, Mizuarai S, Kotani H, Yamaoka S, Miyake K, Aoe S, et al. 2007 Role of the Tolllike receptor 4/NF-kappaB pathway in saturated fatty acid-induced inflammatory changes in the interaction between adipocytes and macrophages. Arteriosclerosis, Thrombosis, and Vascular Biology 27 84-91. (https://doi.org/10.1161/01.ATV.0000251608.09329.9a)

Takikawa A, Mahmood A, Nawaz A, Kado T, Okabe K, Yamamoto S, Aminuddin A, Senda S, Tsuneyama K, Ikutani M, et al. 2016 HIF-1 $\alpha$ in myeloid cells promotes adipose tissue remodeling toward insulin resistance. Diabetes 65 3649-3659. (https://doi.org/10.2337/db160012)

Taniguchi CM, Emanuelli B \& Kahn CR 2006 Critical nodes in signalling pathways: insights into insulin action. Nature Reviews Molecular Cell Biology 7 85-96. (https://doi.org/10.1038/nrm1837)

Tateya S, Kim F \& Tamori Y 2013 Recent advances in obesity-induced inflammation and insulin resistance. Frontiers in Endocrinology 493. (https://doi.org/10.3389/fendo.2013.00093)

Thompson BR, Lobo S \& Bernlohr DA 2010 Fatty acid flux in adipocytes: the in's and out's of fat cell lipid trafficking. Molecular and Cellular Endocrinology 318 24-33. (https://doi.org/10.1016/j. mce.2009.08.015)

Tomblin JK \& Salisbury TB 2014 Insulin like growth factor 2 regulation of aryl hydrocarbon receptor in MCF-7 breast cancer cells. Biochemical and Biophysical Research Communications 443 1092-1096. (https://doi.org/10.1016/j.bbrc.2013.12.112)

Umemura A, Park EJ, Taniguchi K, Lee JH, Shalapour S, Valasek MA, Aghajan M, Nakagawa H, Seki E, Hall MN, et al. 2014 Liver damage, inflammation, and enhanced tumorigenesis after persistent mTORC1 inhibition. Cell Metabolism 20 133-144. (https://doi.org/10.1016/j. cmet.2014.05.001)

Vague P, Juhan-Vague I, Aillaud MF, Badier C, Viard R, Alessi MC \& Collen D 1986 Correlation between blood fibrinolytic activity, plasminogen activator inhibitor level, plasma insulin level, and relative body weight in normal and obese subjects. Metabolism: Clinical and Experimental 35 250-253. (https://doi.org/10.1016/00260495(86)90209-X)

Vandanmagsar B, Youm Y-H, Ravussin A, Galgani JE, Stadler K, Mynatt RL, Ravussin E, Stephens JM \& Dixit VD 2011 The NLRP3 inflammasome instigates obesity-induced inflammation and insulin resistance. Nature Medicine 17 179-188. (https://doi.org/10.1038/ nm.2279) 
Villalba JM \& Alcaín FJ 2012 Sirtuin activators and inhibitors. BioFactors (Oxford, England) 38 349-359. (https://doi.org/10.1002/biof.1032)

Wang L, Fan J, Yan C-Y, Ling R \& Yun J 2017 Activation of hypoxiainducible factor- $1 \alpha$ by prolonged in vivo hyperinsulinemia treatment potentiates cancerous progression in estrogen receptor-positive breast cancer cells. Biochemical and Biophysical Research Communications 491 545-551. (https://doi.org/10.1016/j.bbrc.2017.03.128)

Wazir U, Newbold RF, Jiang WG, Sharma AK \& Mokbel K 2013 Prognostic and therapeutic implications of mTORC1 and Rictor expression in human breast cancer. Oncology Reports 29 1969-1974. (https://doi.org/10.3892/or.2013.2346)

Weisberg SP, McCann D, Desai M, Rosenbaum M, Leibel RL \& Ferrante AW 2003 Obesity is associated with macrophage accumulation in adipose tissue. Journal of Clinical Investigation 112 1796-1808. (https://doi.org/10.1172/JCI19246)

Wellen KE \& Hotamisligil GS 2003 Obesity-induced inflammatory changes in adipose tissue. Journal of Clinical Investigation $\mathbf{1 1 2}$ 1785-1788. (https://doi.org/10.1172/JCI20514)

Wen H, Gris D, Lei Y, Jha S, Zhang L, Huang MT-H, Brickey WJ \& Ting JP-Y 2011 Fatty acid-induced NLRP3-ASC inflammasome activation interferes with insulin signaling. Nature Immunology $\mathbf{1 2}$ 408-415. (https://doi.org/10.1038/ni.2022)

Wensveen FM, Valentić S, Šestan M, Turk Wensveen T \& Polić B 2015 The 'Big Bang' in obese fat: events initiating obesity-induced adipose tissue inflammation. European Journal of Immunology 45 2446-2456. (https://doi.org/10.1002/eji.201545502)

Wentworth JM, Naselli G, Brown WA, Doyle L, Phipson B, Smyth GK, Wabitsch M, O'Brien PE \& Harrison LC 2010 Pro-inflammatory CD11c+CD206+ adipose tissue macrophages are associated with insulin resistance in human obesity. Diabetes 59 1648-1656. (https:// doi.org/10.2337/db09-0287)

Widjaja A, Stratton IM, Horn R, Holman RR, Turner R \& Brabant G 1997 UKPDS 20: plasma leptin, obesity, and plasma insulin in type 2 diabetic subjects. Journal of Clinical Endocrinology and Metabolism 82 654-657. (https://doi.org/10.1210/jcem.82.2.3744)

Wilson BJ, Tremblay AM, Deblois G, Sylvain-Drolet G \& Giguère V 2010 An acetylation switch modulates the transcriptional activity of estrogen-related receptor alpha. Molecular Endocrinology 24 1349-1358. (https://doi.org/10.1210/me.2009-0441)

Wolowczuk I, Verwaerde C, Viltart O, Delanoye A, Delacre M, Pot B \& Grangette C 2008 Feeding our immune system: impact on metabolism. Clinical and Developmental Immunology 2008639803. (https://doi.org/10.1155/2008/639803)

Xu H, Barnes GT, Yang Q, Tan G, Yang D, Chou CJ, Sole J, Nichols A, Ross JS, Tartaglia LA, et al. 2003 Chronic inflammation in fat plays a crucial role in the development of obesity-related insulin resistance. Journal of Clinical Investigation 112 1821-1830. (https://doi. org/10.1172/JCI19451)

Yang Z \& Klionsky DJ 2010 Eaten alive: a history of macroautophagy. Nature Cell Biology 12 814-822. (https://doi.org/10.1038/ncb0910814)

Yang Y \& Yee D 2012 Targeting insulin and insulin-like growth factor signaling in breast cancer. Journal of Mammary Gland Biology and Neoplasia 17 251-261. (https://doi.org/10.1007/s10911-012-9268-y)

Yang W, Schwartz GN, Marotti JD, Chen V, Traphagen NA, Gui J \& Miller TW 2018 Estrogen receptor alpha drives mTORC1 inhibitorinduced feedback activation of PI3K/AKT in ER+ breast cancer. Oncotarget 9 8810-8822. (https://doi.org/10.18632/oncotarget.24256)

Yao Y, Li H, Gu Y, Davidson NE \& Zhou Q 2010 Inhibition of SIRT1 deacetylase suppresses estrogen receptor signaling. Carcinogenesis 31 382-387. (https://doi.org/10.1093/carcin/bgp308)

Yee D \& Lee AV 2000 Crosstalk between the insulin-like growth factors and estrogens in breast cancer. Journal of Mammary Gland Biology and Neoplasia 5 107-115. (https://doi.org/10.1023/A:1009575518338)

Yoshizaki T, Milne JC, Imamura T, Schenk S, Sonoda N, Babendure JL, Lu J-C, Smith JJ, Jirousek MR \& Olefsky JM 2009 SIRT1 exerts antiinflammatory effects and improves insulin sensitivity in adipocytes. Molecular and Cellular Biology 29 1363-1374. (https://doi. org/10.1128/MCB.00705-08)

Yoshizaki T, Schenk S, Imamura T, Babendure JL, Sonoda N, Bae EJ, Oh DY, Lu M, Milne JC, Westphal C, et al. 2010 SIRT1 inhibits inflammatory pathways in macrophages and modulates insulin sensitivity. American Journal of Physiology: Endocrinology and Metabolism 298 E419-E428. (https://doi.org/10.1152/ ajpendo.00417.2009)

Zembutsu H 2015 Pharmacogenomics toward personalized tamoxifen therapy for breast cancer. Pharmacogenomics 16 287-296. (https://doi. org/10.2217/pgs.14.171)

Zhao W, Kruse J-P, Tang Y, Jung SY, Qin J \& Gu W 2008 Negative regulation of the deacetylase SIRT1 by DBC1. Nature 451 587-590. (https://doi.org/10.1038/nature06515)

Zhao H, Wang J, Fang D, Lee O, Chatterton RT, Stearns V, Khan SA \& Bulun SE 2018 Adiposity results in metabolic and inflammation differences in premenopausal and postmenopausal women consistent with the difference in breast cancer risk. Hormones and Cancer 9 229-239. (https://doi.org/10.1007/s12672-018-0329-6)

Zhu C, Qi X, Chen Y, Sun B, Dai Y \& Gu Y 2011 PI3K/Akt and MAPK/ ERK1/2 signaling pathways are involved in IGF-1-induced VEGF-C upregulation in breast cancer. Journal of Cancer Research and Clinical Oncology 137 1587-1594. (https://doi.org/10.1007/s00432-011-1049-2)

Received in final form 31 December 2018

Accepted 7 January 2019

Accepted Preprint published online 7 January 2019 (c) 2019 Society for Endocrinology Published by Bioscientifica Ltd. Printed in Great Britain 